\title{
Multiscale Seismic Tomography Imaging of Volcanic Complexes
}

\author{
Ivan Koulakov \\ Institute of Petroleum Geology and Geophysics, \\ Siberian Branch of Russian Academy of Sciences, \\ Russia
}

\section{Introduction}

Immense scales of volcanic eruptions attracted vital interest of many people since ancient times. It was a long dream of volcano explorers to take a glance inside volcanoes to see the mechanisms responsible for their activity. However, only since the last decades, the development of technologies in geophysics has begun to provide images of the earth structure beneath volcanoes. One of the most powerful methods of geophysical investigations of volcanoes is seismic tomography, a relatively young method, which made a revolutionary breakthrough in the deep earth imaging during the last decades. To study the depths of tens and hundreds kilometers, the geophysicists mostly use the natural sources of seismic signal, earthquakes. These events generate seismic waves which propagate through the earth and accumulate the information on the inner structure of the Earth. The purpose of the seismic tomography method is to decipher this information and to provide the 3D distributions of seismic parameters. In the case of using earthquakes as natural sources an additional problem consists in determining their location coordinates and origin times. Seismic tomography usually provides the distributions of two types of seismic parameters: velocities of compressional and shear (P and S) waves. These parameters have a different behavior depending on several petrophysical conditions; so their joint interpretation may give important informations about the temperature, rheology and composition of deep rocks. Besides two seismic velocities, 3D distribution of seismic wave attenuation (for $\mathrm{P}$ and/or $\mathrm{S}$ waves) is also reported in some cases. Some recent tomographic studies provided the distributions of seismic wave anisotropy which may give a hint about dynamical state of rocks.

In this chapter I will make an overview of different-scale tomographic studies oriented to better understanding the nature of volcanic processes. I do not claim to present in details all variety of different tomographic studies in volcano regions. I will start with a description of various tomographic schemes which can be useful for studying volcano processes on different scales. Then I will provide some real examples of tomographic studies related to different volcanic areas of the world, mostly based on results of projects in which I was personally involved.

\section{Tomographic schemes for studying deep structures beneath volcanoes}

The tomographic investigations of deep structure beneath volcanic areas can be performed on different scales. The regional structures in the mantle, which may achieve dimensions of 
hundreds and thousands kilometers, can be studied using worldwide catalogues of seismic data. In the earth, hundreds of earthquakes are recorded daily by seismic stations located all over the Globe and reported by global agencies, such as International Seismological Center (ISC, 2001). In total, their catalogues contain several millions of travel time picks collected for more than 50 years. Based on these data, a number of global and regional models were constructed. If in a selected area, there are stations and/or sufficiently high seismicity, this enables the presence of many seismic rays travelling in different directions in the target volume (Figure 1). Inversion of these data using the tomographic approaches provides the 3D distributions of $\mathrm{P}$ and $\mathrm{S}$ heterogeneities in the mantle beneath the study area. For example, recent seismic models beneath Europe (Koulakov et al., 2009a) and Asia (Koulakov, 2011) were constructed using this approach.

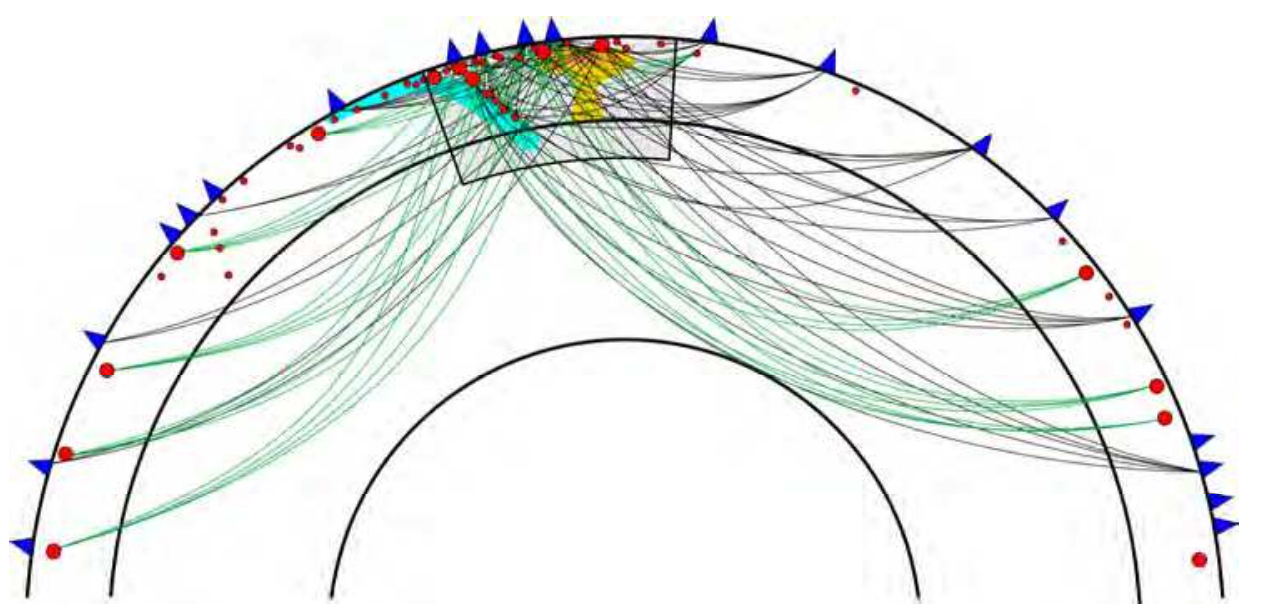

Fig. 1. Schematic distribution of data in the regional tomographic studies. Red circles are the earthquakes; blue triangles are seismic stations of the worldwide network; shaded zone is the target area; green rays correspond to out-of-network events recorded by stations in the target area; black lines depict all available rays from events in the target area recorded by the worldwide stations.

Global and regional tomographic studies based on worldwide seismic catalogues are most appropriate for retrieving the shapes of the slab in different subduction zones where most intensive seismic activity is concentrated. Other contrasted features in the earth having relations with volcanism, mantle plumes, can also be studied by regional tomography, but they are much harder objects to investigate by seismic tomography than slabs. First of all, in plume areas the seismicity is usually much weaker and is located only at shallow depths. Second, due to Fermat principle, seismic wave tends to travel mostly through high velocity patterns and avoid low-velocity plume-related anomalies. It is believed that plumes in the mantle have the shape of thin vertical channels of about $100 \mathrm{~km}$ thickness with contrasted low-velocity properties inside. In this case, seismic rays would overturn the plume and would accumulate almost no information about it. Even in cases of ideal ray coverage, regional tomography would only be able to retrieve the indirect evidences of plume existence, such as large warmer areas around plumes, but not the shape of the plume itself. 
In some extent, this problem can be solved if instead of ray theory, one use finite frequency approach (Montelli et al., 2004). In this approximation, the seismic waves propagate along «fat» rays (areas with variable sensitivity) which may accumulate more rich information about plumes than line-representation of seismic rays.

Talking about regional studies I have to shortly mention surface wave tomography studies. Surface waves propagate along the Earth surface; the amplitudes of particle motions due to surface wave are maximal at the surface and decrease with depth. Two distinct types of surface waves are observed: Love waves, whose associated displacement is parallel to the free surface and perpendicular to the direction of propagation (toroidal), and Rayleigh waves, with displacement on a plane perpendicular to Love-wave displacement (spheroidal). The main feature of surface waves that allows using them for tomography is that their velocity strongly depends on the frequency. The velocity of surface wave is an integral value of the shear velocity distribution in the layer where the wave effectively propagates; lower frequency of the signal corresponds to the thicker layer (a kind of skin effect which is observed in different branches of wave physics). Thus, if the velocity increases with depth, low-frequency modes of surface wave have higher speed, as embracing thicker layers of the Earth. As a result, multi-frequency surface wave packets are clearly observed to disperse as they propagate away from their source. From the point of view of tomography, this means that surface-wave signal filtered at different frequencies will correspondingly provide information about different depth ranges of the Earth. These properties of surface waves are widely used in global and regional tomographic studies.

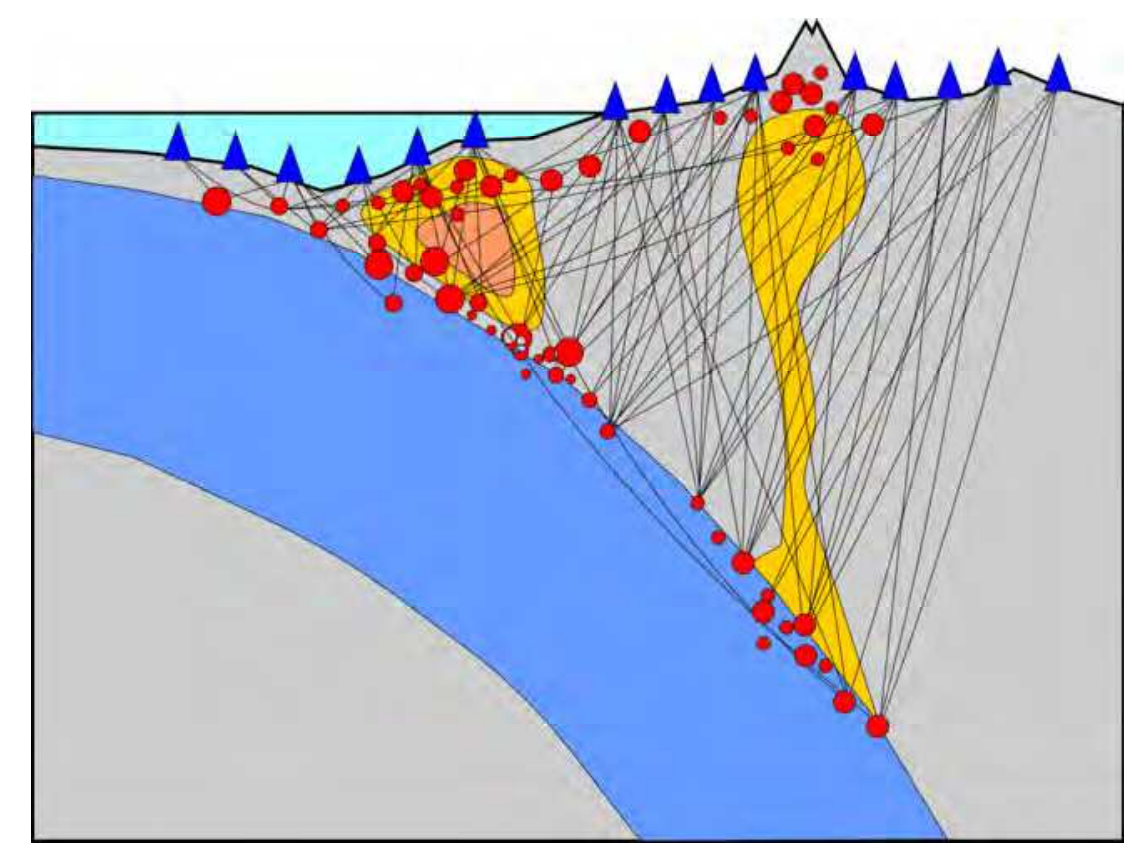

Fig. 2. Schematic distribution of data in local earthquake studies. Red circles are the earthquakes; blue triangles are seismic stations deployed in the study area; black lines depict all rays used in local earthquake studies. 
For smaller scale studies, temporary networks are installed in target areas and operate for a limited time period continuously recording seismic signal. Among variety of approaches used to process data of local seismic networks, in our studies we mostly use two tomographic schemes: local earthquake and teleseismic tomography. Local earthquake tomography (Figure 2) uses the travel times of $\mathrm{P}$ and $\mathrm{S}$ seismic waves from sources occurred in the study area. In this case, the inversion should be performed simultaneously for seismic velocities and source parameters (coordinates and origin times). The location of sources and configuration of the ray paths strongly depend on the unknown velocity distribution. Thus, this problem is strongly non-linear and its solution is usually performed by iterative repetition of several linearized steps. This scheme is especially productive for areas with intermediate depth seismicity, such as in subduction zones (see an example in Figure 2). This gives us a possibility to investigate the 3D seismic structure above seismic clusters.

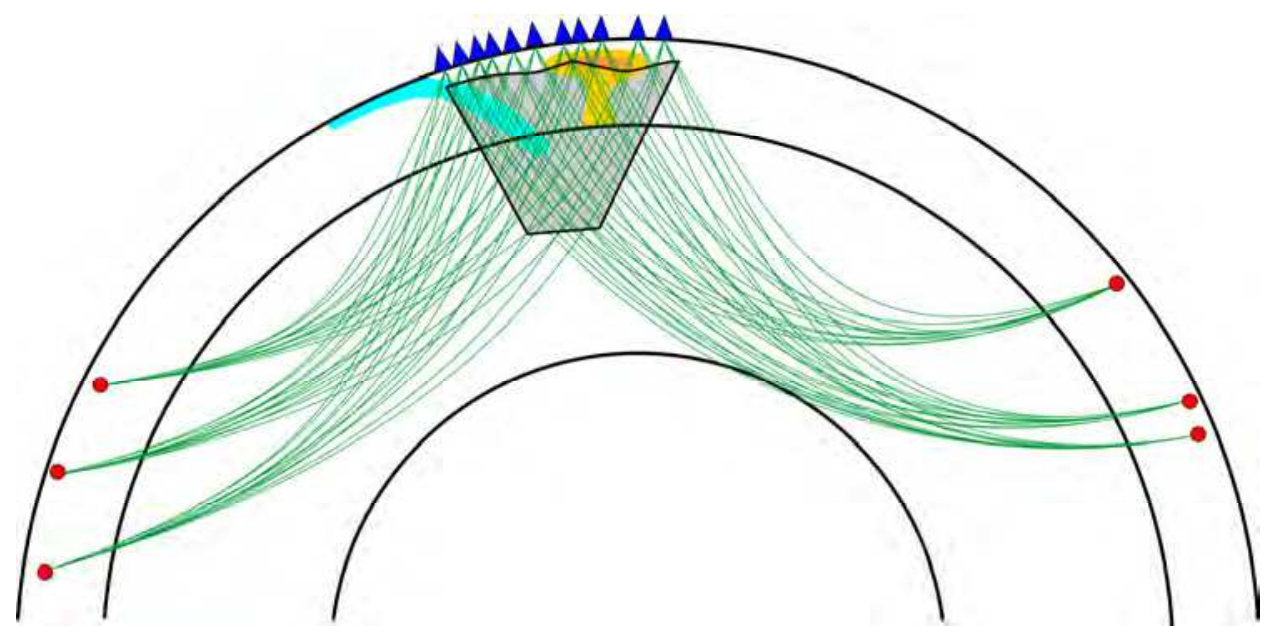

Fig. 3. Schematic data distribution in teleseismic tomography studies. Red circles are the teleseismic earthquakes; blue triangles are seismic stations of the regional network; shaded zone is the resolved area where rays intersect in different directions; green rays correspond to teleseismic rays.

Teleseismic studies (Figure 3) are based on using records of local station networks from remote events which are mostly based on the so called $\mathrm{ACH}$ approach named after the author names (K. Aki, A. Christoffersson and E.S. Husebye) of a classical work by Aki et al, (1977) which is considered as one of the first practical applications of seismic tomography. Practical algorithms for this approach were developed by Evans \& Achauer (1993), van Decar \& Crosson (1990) and others and they are actively used in dozens of different studies. The epicentral distances to the events selected for teleseismic studies are usually larger than 30 degrees. This produces steep seismic rays which cross the lower border of the study volume. This helps to avoid any regular bias in the resulting velocity models caused by heterogeneities in the upper mantle in neighboring areas. The waveforms of teleseismic signal recorded simultaneously by the stations of the network usually have similar shapes, but arrive with some delays which can be identified by cross correlation. These relative delays are the input data for the tomographic inversion which provides relative seismic 
anomalies, but incapable to give any constraint on absolute velocities. The major problem of teleseismic scheme is considerably lower vertical resolution in respect to horizontal, which is caused by steep ray orientation. Taking into account the fact that tomographic inversion can work only in areas where rays cross in different direction, the upper limit of the resolved area in teleseismic studies is roughly at a depth where "ray tubes" from neighboring stations start to intersect. This depth approximately corresponds to the average distance between stations in the network. With depth, the size of the resolved area decreases like an inverted cone; the maximal depth is roughly equal to the diameter of the network.

According to the above paragraphs, teleseismic and local earthquake schemes use completely different data. In most local earthquake studies all the events located outside the network perimeter are not taken into consideration. In teleseismic studies, the selection of the events starts only from the epicentral distances of 25-30 degrees ( $3000 \mathrm{~km})$. So when processing data from temporary networks, no data corresponding to regional distances between the network perimeter and about $3000 \mathrm{~km}$ are used. In my opinion, this is obviously shame, because regional data contain very important information about structure in the target area which can be deciphered by tomography. Furthermore, these data enable strong variety of ray orientations in the target area that is very important to increase the resolution capacity of tomography. I believe that all these data can be inverted together that may provide the results of better quality than in cases of separate local earthquake and teleseismic tomography. The advantages of using data from regional events in local earthquake tomography scheme are illustrated by Koulakov (2009b).

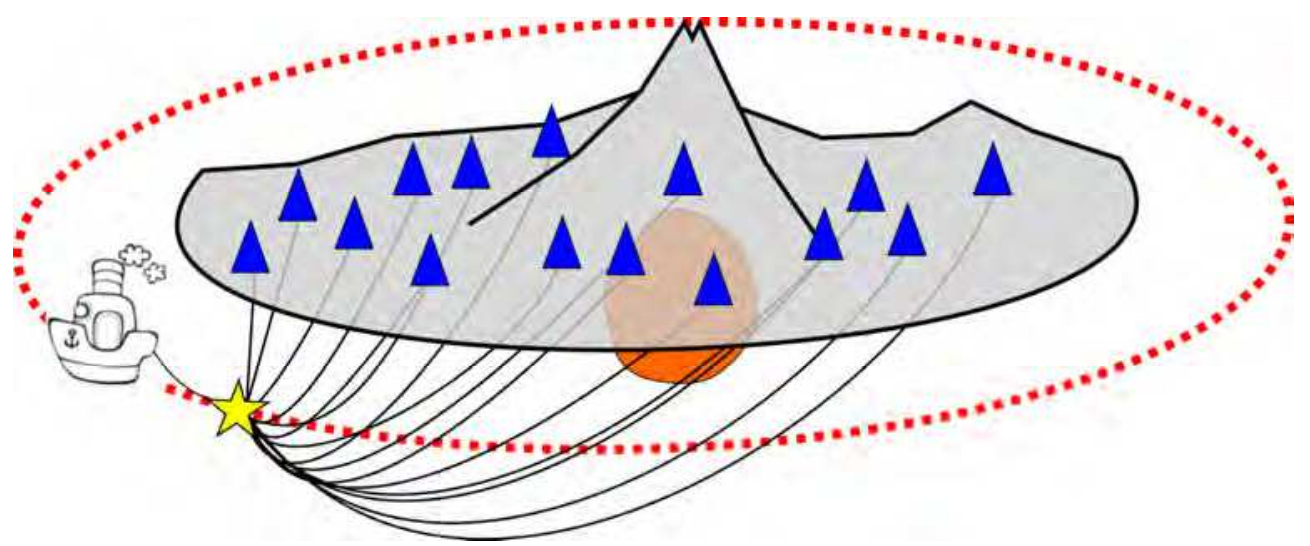

Fig. 4. Example of 3D active source studies based on marine airgun shots recorded by onshore stations. Blue triangles depict stations; yellow star is one of the shots along the path of the vessel (red dotted line). Black lines represent seismic rays.

In last years some alternatives of travel time tomography appeared. One of the tomography schemes which do not use seismic rays is ambient noise tomography which cross-correlate the microseismicity signal in different combinations of stations that finally gives the distribution of S-velocities. This method has been applied in some volcanic areas. For example, Stankiewicz et al., (2010) used ambient noise tomography and data from 40 temporary seismic stations to clearly image the magma chamber beneath Lake Toba caldera, one of the largest Quaternary calderas on Earth. Another method is based on surface waves 
recorded in local stations. Based on different group and phase velocities, one can get the 3D distribution of $S$ velocity beneath the target area.

Active source studies with the use of artificial seismic sources are also used to investigate some volcanic systems. There were some examples of onshore studies in volcanic areas with the use of several explosions, mostly for profile observations (e.g. Aoki et al., 2009). However, the signal produced in such experiments was fairly weak to penetrate deeply. Seismic waves are strongly scattered in highly heterogeneous structures beneath volcanoes and, in most cases, seismic processing of these data hardly provides any reasonable structures. In addition, strong land explosions are forbidden in most volcanic areas. A most commonly used way in active source observations is generating seismic signal by airguns installed on research vessels (Figure 4). This scheme can be used for studying underwater and island volcanoes, or those located close to the Sea shore. A great amount of airgun shots enables special data processing which allows retrieving the signal of relatively high quality. In recent years these kinds of experiments have increased and provided high resolution images of volcanic regions, for example, Vesuvius (Italy) (di Stefano \& Chiarabba, 2002, Zollo et al., 2002), Campi Flegrei (Italy) (Zollo et al., 2003), Deception Island (Zandomeneghi et al. 2009), and Montserrat Island (Paulatto et al., 2010).

Below I consider several examples of real studies that give information about deep sources of volcanism in different regions. In the worldwide scientific literature, there is a huge amount of papers on this topic, and obviously I do not pretend to cover all of them. In the following sections I will make an overview of some studies in which I was personally involved.

\section{Regional-scale studies (1000s km size): Link between hot mantle and intracontinental volcanism}

When considering links between deep mantle structures and volcanic complexes on a regional scale, the most important features in the mantle are thought to be plumes, convective cells and slabs. As mentioned in the previous chapter, plumes, as thin contrasted channels in the mantle, are difficult objects for the tomographic approach, because seismic rays tend to overpass the plumes and do not accumulate any information about them. At the same time, indirect evidences of plumes, such as heating of the mantle, can be detected robustly as large low-velocity anomalies. Most regional and global tomographic models of the upper mantle reveal close correlation between the distributions of intra-plate Cenozoic volcanic fields and low-velocity anomalies which can be interpreted as areas of higher temperature in the upper mantle.

\subsection{Mantle structure beneath volcanic fields in Europe}

An example of the distribution of Pn velocity anomalies just below the crust in Europe and Mediterranean is shown in Figure 5. This model was computed by Koulakov et al., (2009a) from inversion of several millions of travel times from the ISC catalogue based on the regional tomographic scheme (Figure 1). The calculations were separately performed in 12 overlapping circular windows and then the results were composed by averaging in one model. The reliability of this model was thoroughly verified by a number of different tests presented in Koulakov et al., (2009a). Note that this model seems to be consistent with regional and global models constructed by other authors (e.g. Piromallo \& Morelli, 2003, Bijwaard et al., 1998). 
Comparison of the tomographic model with Cenozoic tectonic units in Europe presented in Figure 5 shows that most of the volcanic fields appear to be associated with low velocity anomalies in the uppermost mantle. For example, the volcanic complex of the French Massif Central (MC) perfectly fits with an isometric low-velocity pattern. Similar features, although not as sharp, are located beneath the Cenozoic volcanic fields in Eastern Pyrenees, Eifel area, Bohemian and Pannonian massifs. These volcanic fields seem to be related to overheated parts of the upper mantle which can be attributed to ascending flows in active mantle convection. We propose that this convection can be activated by complex subduction features in the collision zones between European and African plates. At the same time, we do not see any evidences that the volcanism in these areas of Europe can be caused by plumes, thin highly contrasted channels in the upper mantle.

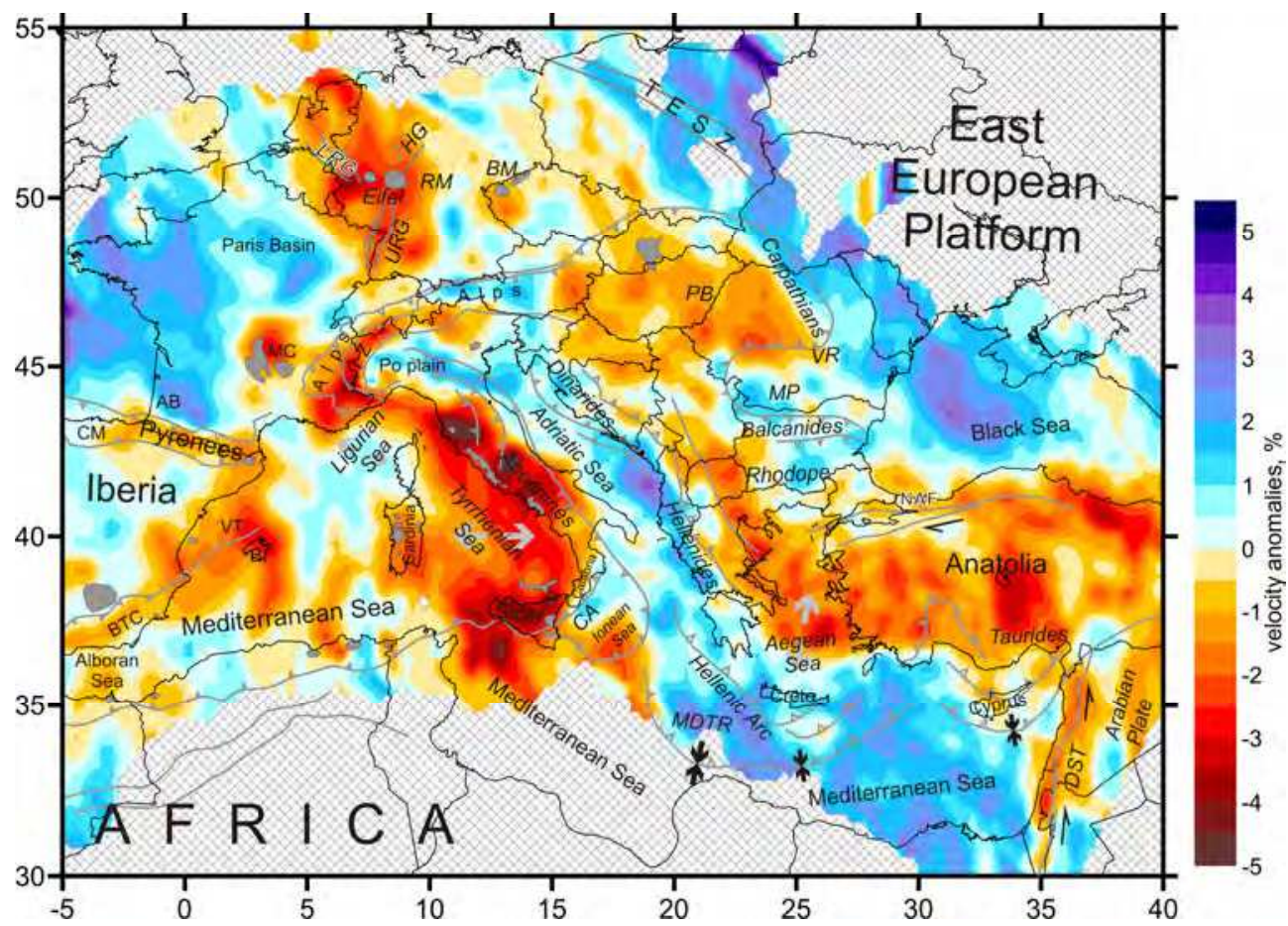

Fig. 5. The distribution of $P$ velocity anomalies in the uppermost mantle beneath Europe and Mediterranean, just below Moho, from regional tomographic study by Koulakov et al., (2009a). Main geographic and tectonic elements in the study area modified after Faccenna et al (2003). Grey spots indicate the main Cenozoic volcanic fields. Abbreviations: AB Aquitaine Basin, BI - Balearic Islands, BM - Bohemian Massif, BTC - Betic Cordillera, CA Calabrian Arc, CM - Cantabrian Mountains, DST - Dead Sea Transform, HG - Hessian Graben, IZ - Ivrea Zone, LRG - Lower Rhine Graben, MP - Moesian Platform, MC - Massif Central, MDTR - Mediterranean Ridge, NAP - North Anatolian Fault, PB - Pannonian Basin, PRM - Rhenish Massif, TESZ - Trans European Suture Zone; URG - Upper Rhine Graben, VR - Vrancea, VT - Valencia Trough, WC - West Carpathians. 
Some of the mentioned volcanic fields were previously studied in more details using temporary seismic networks and based on the teleseismic approach. For example, French Massif Central was studied by Granet et al., (1995). This model was used to estimate the temperature beneath MC (Sobolev et al., 1997). Another example of "searching for a plume" by tomographic approaches is teleseismic inversion for the area of Eifel volcanic field by Ritter et al., (2001). These and other studies in areas of Cenozoic volcanism in Europe found low velocity anomalies beneath the volcanic fields; however they look rather as large continuous features than sharp plume-shaped channels. It can be due to limited resolution enabled by ray-based tomography which is especially serious when long wavelength teleseismic rays were used. In this context, frequency-dependent tomography would be especially important; however it was not implemented for these areas. All these observations make us doubt in existence of plumes in Europe.

Many authors attribute the volcanism in the Central Mediterranean area to subductionrelated magmatism (e.g. Dercourt et al., 1986; Lustrino, 2000) caused by closing of the Tethys Ocean. However, the composition variability of volcanic products around the Tyrrhenian Sea (e.g., Bell et al., 2004, 2006) may indicate to both mantle and subduction-related sources of magmatism. For example, carbonatites and kamafugites in Intramontane Province of Italy can only be explained in the frame of a plume model (Lavecchia et al., 2006). Based on geochemical analyses, Laveccia and Stoppa (1996) claim that a mechanism of intracontinental passive rifting in the Tyrrhenian and Adriatic Seas, which drives mantle upwelling, is sufficient to satisfy the petrological and geochemical constraints and the observed tectonic environment without requiring a subduction plane. At the same time, the facts of mantle genesis of some volcanic rocks in Mediterranean cannot automatically distinguish whether they are related to plumes or to large overheated areas in zones of ascending convective mantle flows.

Zones of active volcanism around the Tyrrhenian Sea, which includes volcanic fields in Sicily, volcanoes along the SW coast of Appennines and Cenozoic volcanic manifestations in Sardinia, are lying along the perimeter of a large low-velocity anomaly which covers the entire Tyrrhenian basin. We propose that these volcanic manifestations are related with the subduction processes. It is thought that beneath the Tyrrhenian Sea two subductions occur in different directions. The volcanoes along the SW coast of Apennines can be a kind of volcanic arc above the Adriatic plate subducting to SW direction. Volcanoes of Sicily probably form the arc above the Calabrian slab which subducts to NW direction. The other centers of volcanism in the Tyrrhenian and Adriatic Seas can be due to mantle upwelling and microplumes (e.g., Lavecchia et al., 2006, Bell et al., 2006). The latter are too small to be resolved by tomography.

\subsection{East African Rift system: Plumes or convective flows?}

In this section I will present an example of regional tomography study in the area of the East African Rift System (EARS) and will discuss its relationship with the volcanic processes. EARS is the largest continental rift system on the Earth where active volcanic manifestations occur in Cenozoic. In the Afar Triple Junction (ATJ), fast extension of the lithosphere causes the origin of two oceanic basins, Red Sea and Golf of Aden, and the Ethiopian segment, which is the unique place on the earth where spreading of the lithosphere takes place onshore.

The origin and mechanisms of processes in EARS is a hot topic which is actively debated in the literature (see an overview in Chang and Van der Lee 2011). In particular, one of the 
main questions is whether the entire system is driven by one plume beneath ATJ, or by several flows along the EARS. To answer this question, a lot of different geological and geophysical studies were performed. In particular, deep seismic structure beneath different segments of EARS was investigated in various seismic studies. Regional travel-time tomography by Benoit et al. (2006) shows presence of a single plume beneath the Ethiopia. Results of SKS-splitting analysis (Hansen et al., 2006) and tomography Park et al. (2007, 2008) suggested presence of the channeled mantle flow from the Afar hot spot. A number of studies are dedicated to investigations of relatively small segments of the EARS using different tomographic methods (e.g. Daly et al., 2008; Jakovlev et al., 2011; Park and Nyblade, 2006; Tongue, 1992).

Here I present a regional tomographic model of the upper mantle beneath the EARS constructed by Koulakov (2007) and based on global catalogues using the regional tomographic scheme shown in Figure 1. The data amount and quality in this study is much lower than in Europe, and the spatial resolution in this case is much poorer. This study presented several tests, including synthetic modeling with realistic shapes of patterns, which directly demonstrate the limitations of the resolution with this dataset. These tests show that we cannot detect a plume, although very large; we are only able to see traces of indirect effect of the plume upon the surrounding areas.

In Figure 6, two horizontal sections, which correspond to the uppermost mantle and bottom of the upper mantle, are shown. In the shallower section, the tomographic image clearly highlights general geological features of the region. The Tanzania Craton is represented by high-velocity anomaly; volcanic fields in Western and Eastern Branches of the EARS surrounding the Craton coincide with low-velocity belts. Beneath the Ethiopian segment of the EARS, where most active rift processes and related volcanism are observed, the tomographic model provides intensive low-velocity anomalies. In the Afar Triple Junction (ATJ), the situation seems to be more complicated. Just in the middle of ATJ, we observe higher P-velocity anomaly, whereas the $\mathrm{S}$ anomaly is negative in the same location. One of possible explanations for higher P-velocity in the uppermost mantle could be the presence of very thin crust in the Red Sea and Gulf of Aden which is responsible for negative delays of seismic rays. In S-velocities this pattern is not seen due to significantly lower resolution. Another explanation can be related to petrophysical properties of rocks inside the plume. Higher P-velocity, which is more sensitive to the composition of rocks, might represent the existence of deeper rocks brought by the plume from the mantle. S-velocity is more sensitive to the presence of fluids and melts; thus low S-anomaly may reflect the rocks with high melting degree located in the top of the plume.

In deeper sections we observe two separate isometric low-velocity patterns of similar size (about $700 \mathrm{~km}$ width, highlighted with red dotted lines) which are located beneath the Tanzania Craton and ATJ. These anomalies, having the width compatible with height, cannot be directly called plumes. One explanation is that these are ascending branches of convective flows in the upper mantle. We cannot exclude that inside these flows there are thin plumes which affect chemically or thermally the surrounding rocks. However, this tomographic model does not have enough resolution to confirm of disprove this statement. In the lower plot of Figure 6, a qualitative interpretation of the result along the profile passing through Western Rift, Tanzania Craton, Eastern Rift, Ethiopian Rift and ATJ. We claim that there are two approximately equal ascending flows beneath Tanzania Craton and ATJ which behave differently in shallower part of the mantle. Beneath ATJ and the 
Ethiopian segment, this hot flow causes strong extension of the lithosphere which is manifested by spreading, rifting and volcanic activity. The flow beneath Tanzania Craton meets the bottom of thick lithosphere, but it is not capable to destroy it. As a result, this flow follows the bottom of the lithosphere and reaches the surface at the perimeter of the craton. The volcanic and rifting processes in the Western and Eastern branches are considerably weaker than those around the ATJ and the Ethiopian segment.
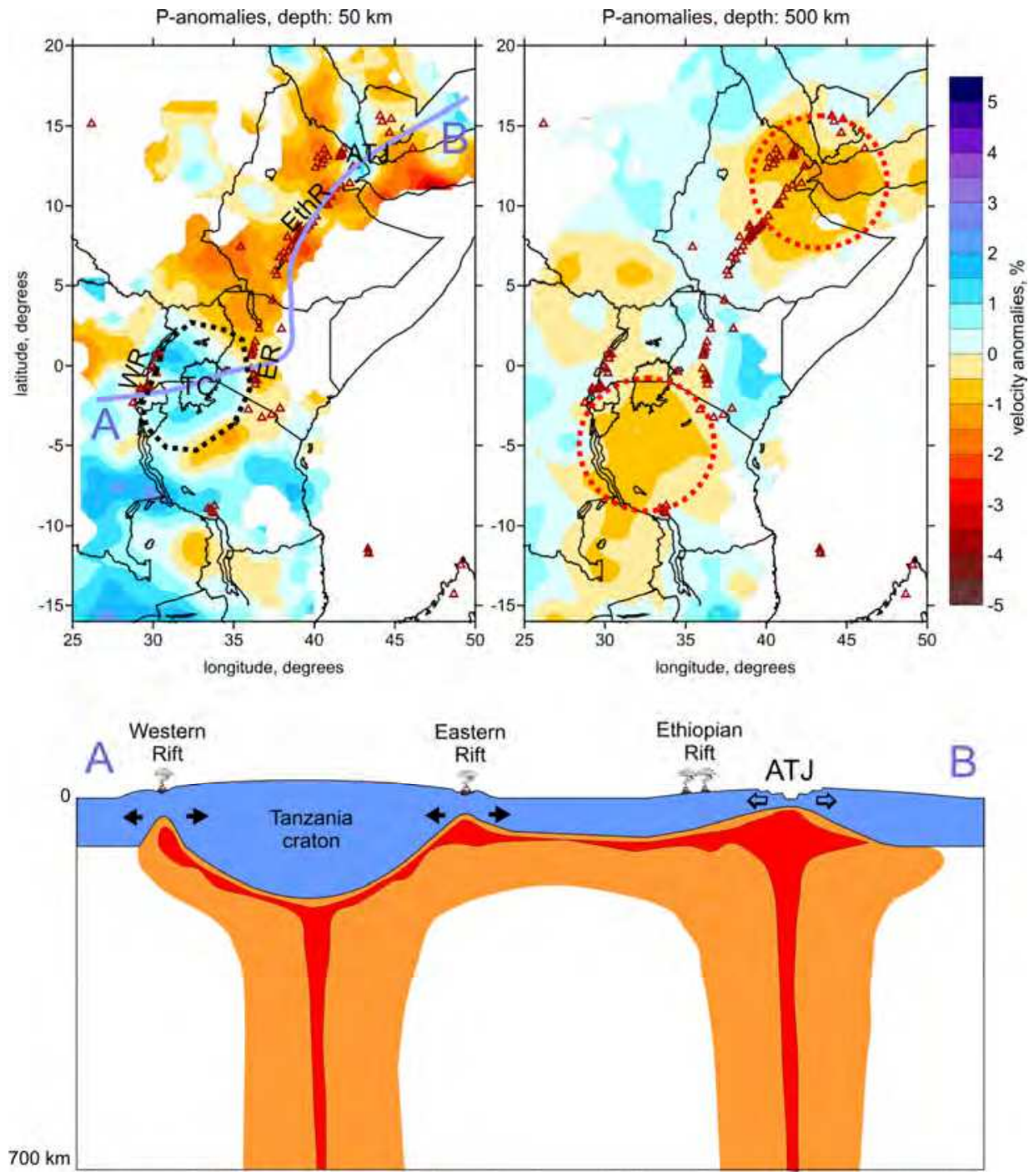

Fig. 6. Upper plots: results of regional tomographic study by Koulakov (2007) in the area of the East African Rift System at $50 \mathrm{~km}$ and $500 \mathrm{~km}$ depth; lower plot: qualitative interpretation along the profile A-B (violet line) which pass through Western Rift (WR), Tanzania Craton (TC), Eastern Rift (ER), Ethyopian Rift (ER) and Afar Triple Junction (ATJ). 


\subsection{Siberia and Mongolia: Overheated mantle beneath basaltic fields}

The last example of a regional tomographic study related to zones of intraplate Cenozoic volcanism corresponds to the area of Siberia and Mongolia. Logachev et al. (1996) and Logachev (2005) evaluated the total amount of Cenozoic erupted material in Southern Siberia and Mongolia as $6000 \mathrm{~km}^{3}$ (yellow fields in Figure 7). Roughly half of this amount corresponds to the Sayan area along the southern border of the Siberian craton. It is interesting that in Lake Baikal, which is the main rift depression of Siberia, no signature of Cenozoic volcanism has been observed (e.g., Eskin et al., 1978). Another volcanic field is related to the Hangay dome in Mongolia. Analysis of magma compositions in both areas has shown that they have generally similar properties (e.g., Yarmoluk et al., 1990), which probably indicates their common source. Rasskazov et al. (1993) estimated the depth of their origin as $50-150 \mathrm{~km}$, while the geochemical analysis by Ashepkov et al. (1996) provided an argument for a greater depth of the magma sources. The youngest manifestations of volcanism are observed in Eastern Sayan.

Here I present the results of tomographic inversion by Koulakov and Bushenkova (2010) which was based on travel time data from global catalogues. Most of the area of Siberia is seismically passive, and a very few stations are installed there. The regional schemes presented in Figure 1 can be used for studying the seismically active southern part of Siberia and Mongolia (Koulakov, 2008). However it cannot provide any resolution in most parts of the Northern Siberia where neither stations, nor seismicity are presented. To fill the gaps in ray coverage, we used the PP phases which corresponded to seismic rays with one reflection from the Earth surface. When considering both PP and P phases, their difference gives information about seismic anomalies around the reflection point. For this study, we selected all PP rays having reflection points inside the study area. Note that these data are quite noisy, and their distribution does not allow computing high-resolution models. For areas with active seismicity and/or dense seismic networks, PP data had smaller weight compared to regular data. However, in case of absence of events and/or stations, these data play the major role for constructing velocity models.

In tomographic images, Koulakov and Bushenkova (2010) observed a clear correlation between the main seismic patterns and Cenozoic volcanic fields (Figure 7). This correlation was especially clear at shallower depths $(50-100 \mathrm{~km})$, where the amplitudes of anomalies beneath the volcanic areas reached $2 \%$. For deeper sections, the anomalies were much weaker (approximately $0.5 \%$ ) and displaced with respect to the volcanic fields.

The presence of several plumes beneath Mongolia and southern Siberia, as well as their link with Cenozoic volcanism, was proposed by Zorin et al. $(2002,2003)$ based on long wavelength gravity anomalies. However, these individual plumes were not visible in the tomographic inversion results reported here and elsewhere. Taking into account the deep nature of the magmas revealed by geochemistry studies (e.g., Ashepkov et al., 1996), we believe that the plumes may exist, but their sizes are too small to be resolved by seismic tomography. These plumes might provide the general anomalous thermal background beneath Sayan and Mongolia that is observed in our tomograms as one regional low velocity anomaly.

One of these plumes is probably located beneath the southern part of the Siberian craton. It was visible as a low velocity anomaly in our tomograms at depths of $400 \mathrm{~km}$ and deeper. This plume may accumulate hot material on the bottom of the cratonic lithosphere. While reaching a critical mass, this material starts moving up toward the border of the Siberian craton, where it produces fields of volcanic activity. 

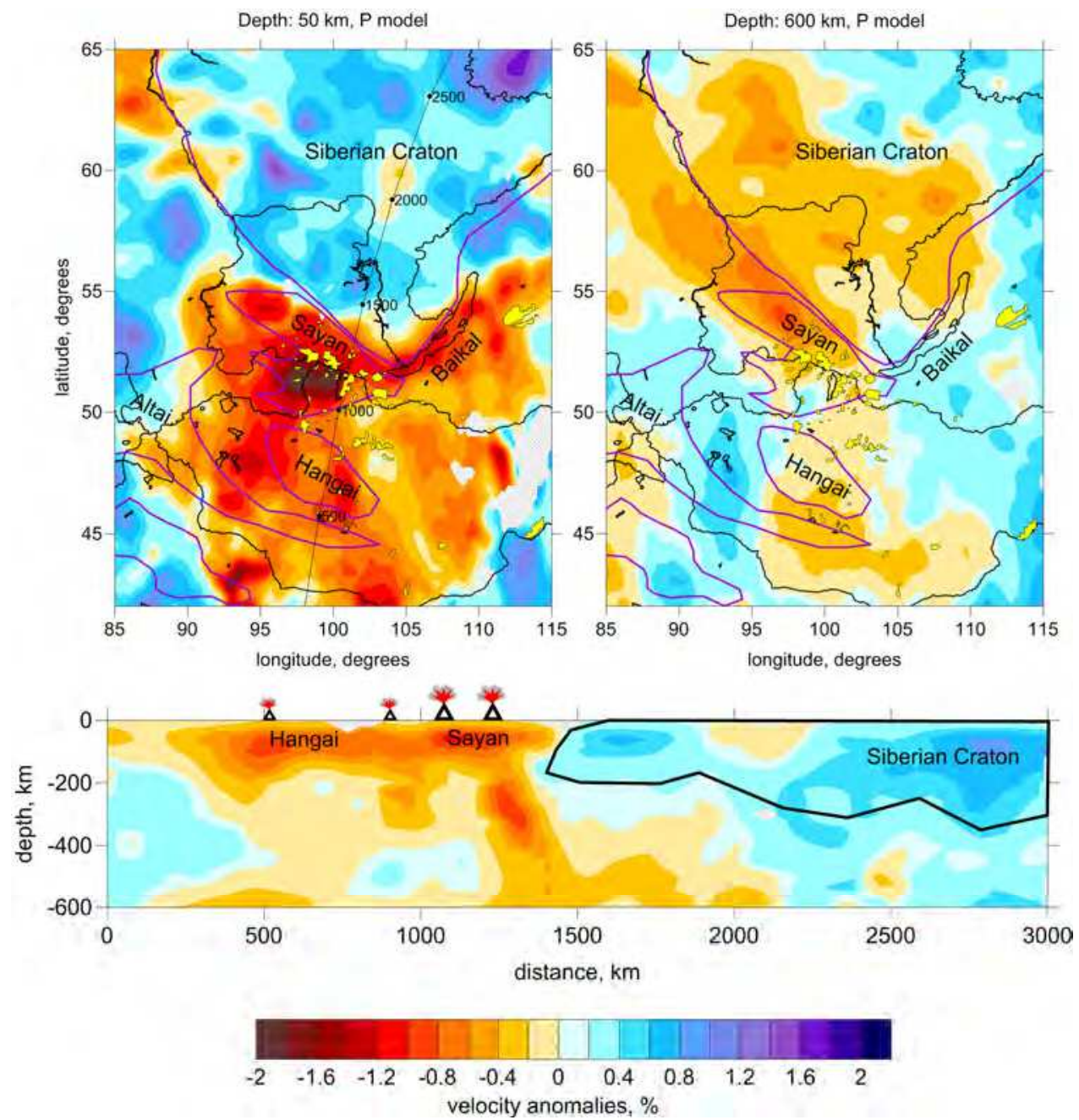

Fig. 7. P-velocity anomalies beneath Siberia and Mongolia from tomographic inversion of global P and PP data. Upper plots show two horizontal sections at 50 and $600 \mathrm{~km}$ depth. Yellow area depict the areas of Cenozoic basaltic volcanism. Violet lines highlight the main tectonic units. Lower plot show the resulting model in vertical section (location of the profile is shown in $50 \mathrm{~km}$ map). Hypothetical shape of the Siberian Craton is shown with black line. Locations of the main volcanic fields are indicated with volcano symbols.

\section{Local earthquake tomography can reveal the link between subducting slab and volcanic arc}

\subsection{Toba Caldera: Can we see deep traces of super eruptions?}

The Toba volcanic complex, located in northern Sumatra, Indonesia, is part of a 5,000 km long volcanic chain along the Sunda arc. Toba volcano produced the largest known volcanic 
eruption on the Earth during the past 2 million years (Smith \& Bailey, 1968). About 74,000 years ago, around 2,800 cubic kilometers of magma were erupted and had a significant global impact on climate and the biosphere. The eruption led to the final formation of one of the largest calderas, the $35 \times 100 \mathrm{~km}$ wide Toba caldera. Super scale eruptions at Toba have occurred several times (at least four eruptions of more than VEI 7 over the last 2 million years). In this sense, Toba seems to be a singularity in a chain of more than one hundred other volcanoes with explosive potential along the Sunda arc. The reasons for this unique behavior of the Toba volcanic activity are not yet clearly understood. As suggested by Bachmann and Bergantz, (2008), the explosive magma in super eruptions are produced by extracting interstitial liquid from long-lived "crystal mushes" (magmatic sponges containing $>50 \mathrm{vol} \%$ of crystals) and collecting it in unstable liquid-dominated lenses. If there is a potential of a new super eruption, such signatures should be clearly seen in tomograms.
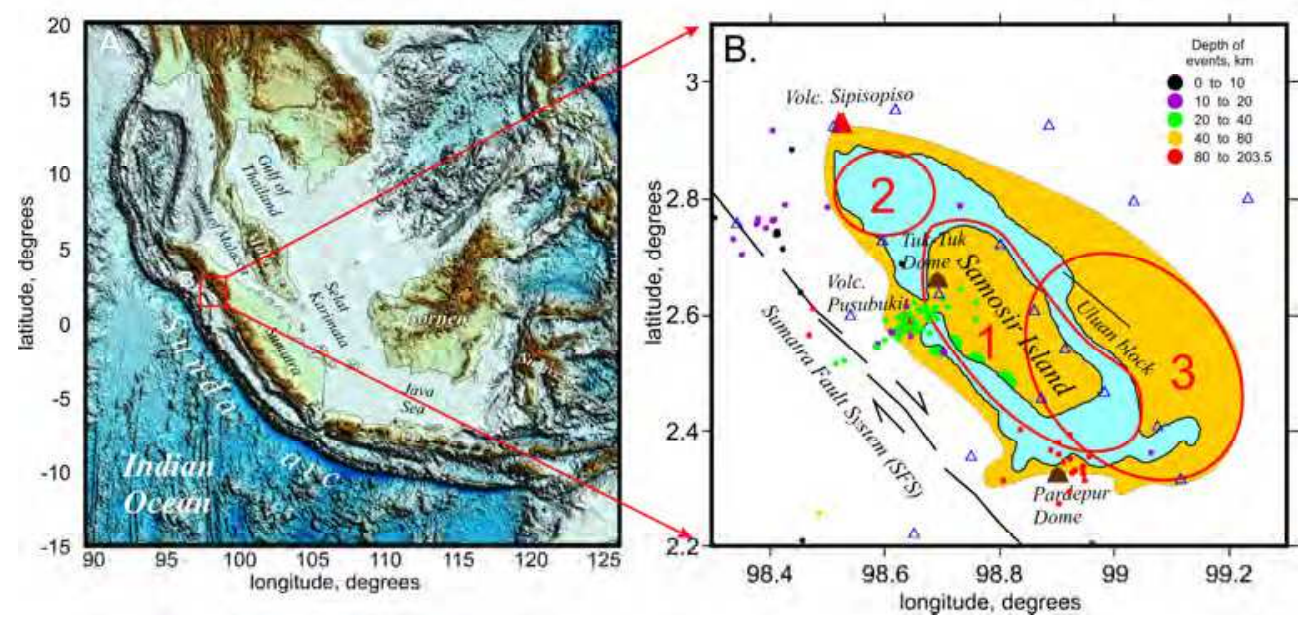

Fig. 8. Study region in the context of the Sunda Arc. A. Bathymetry and topography of the Sunda Arc and surrounding areas. B. The main structural elements of Toba caldera. Yellow areas are the present-day topographic depression; green indicates uplifted areas. Red ellipses mark different caldera units. 1 Sibandung caldera: created 74,000 years ago by the Toba YTT event (Young Toba Ash); 2 Haranggaol caldera: formed 500,000 years ago by the Toba MTT event (Middle Toba Ash); 3 Sibandung caldera: formed 800,000 years ago by the Toba OTT event (Old Toba Ash).Blue triangles depict stations; colored dots are the events used in this study.

Here I describe a tomographic model of the crust and uppermost mantle beneath the Toba Caldera constructed by Koulakov et al., (2009b). This work was based on a dataset corresponding to a rather old local seismic experiment and includes the travel time picks collected by seismic network around Toba which was operated for about 4 months (JanuaryMay, 1995) by Indonesian teams in cooperation with IRIS and PASSCAL. The network recorded 1,500 local earthquakes; however, for this study only the 390 most reliable events were used (Figure $8 \mathrm{~B}$ ). A special attention in this study was addressed to the verification of the model. In particular, a synthetic model with realistic configuration of anomalies was 
constructed, so that the results of synthetic and real data inversion were almost identical both in shapes and amplitudes. This allowed assessing true magnitudes of anomalies.

Results of tomographic inversion are presented in Figure 9. Beneath the Toba Caldera and other volcanoes of the arc we observe relatively moderate (for volcanic areas) negative $\mathrm{P}$ and $S$ velocity anomalies which reach $18 \%$ in the uppermost layer, $10-12 \%$ in the lower crust and about $7 \%$ in the uppermost mantle. Much stronger contrasts are observed for $\mathrm{Vp} / \mathrm{Vs}$ ratio which is a possible indicator of dominant effect of melting in origin of seismic anomalies. At a depth of $5 \mathrm{~km}$ beneath active volcanoes we observe small patterns (7-15 km size) with high $\mathrm{Vp} / \mathrm{Vs}$ ratio which might be an image of actual magmatic chambers filled with partially molten material feeding the volcanoes. In the mantle wedge we observe a vertical anomaly with low $\mathrm{P}$ and $\mathrm{S}$ velocities and high $\mathrm{Vp} / \mathrm{Vs}$ ratio which link the cluster of events at 120-140 km depth with Toba caldera.
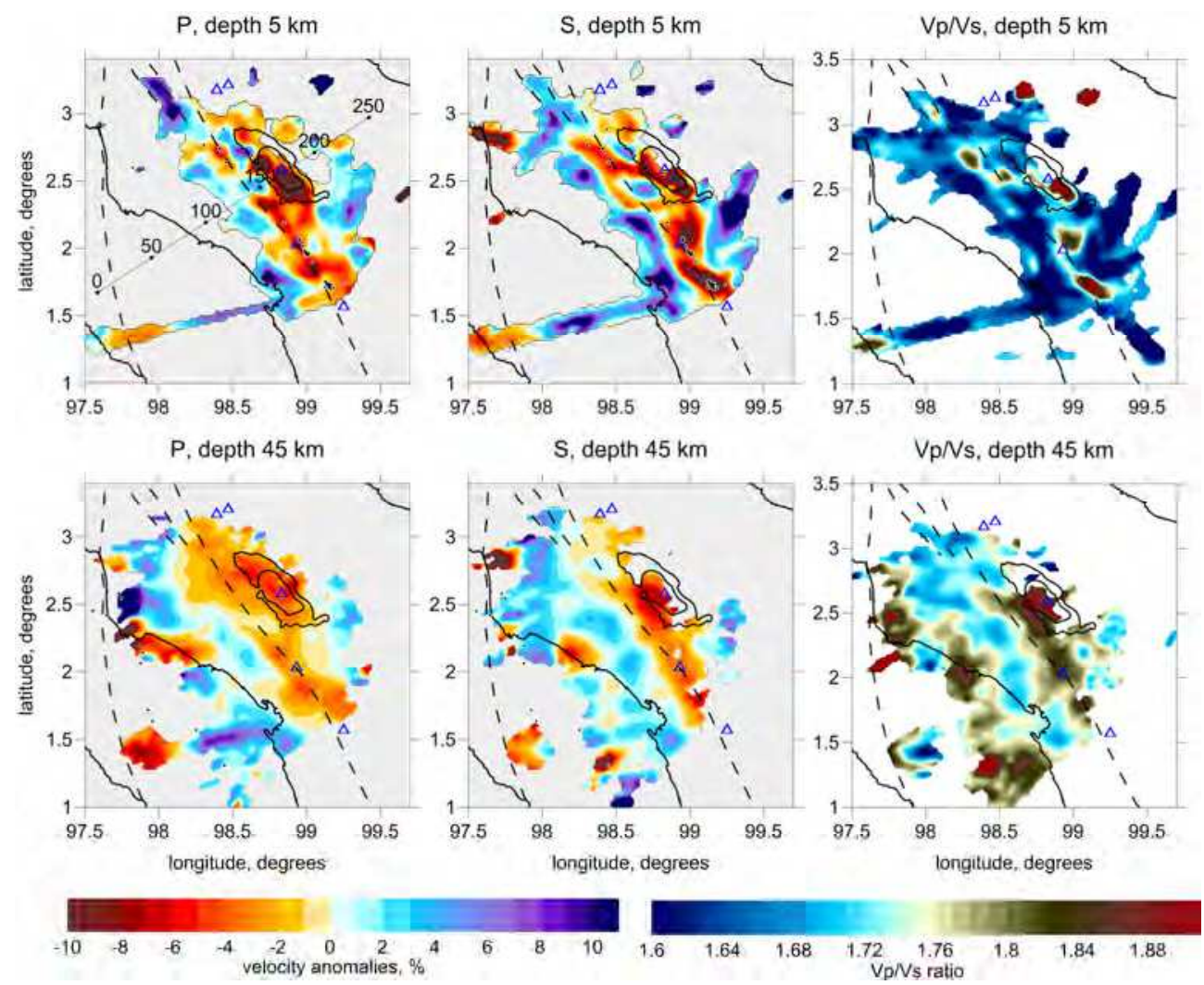

Fig. 9. $\mathrm{P}$ and $\mathrm{S}$ velocity anomalies and $\mathrm{Vp} / \mathrm{Vs}$ ratio in the area of Toba Caldera in two horizontal sections. Black dots indicate the final locations of sources in a corresponding depth interval. Blue triangles show positions of active volcanoes. Dotted lines indicate the locations of the Mentawai and Sumatra fault zones. Positions of the profile for cross section in Figure 10 is given in the plots for $P$ anomalies at $5 \mathrm{~km}$ depth. 
The seismic structure beneath Toba allows quite clear interpretation which is illustrated in Figure 10. We observe a vertical low-velocity pattern which links the seismicity cluster at 130-150 km depth with the Toba Caldera. The most probable explanation for this link is that the phase transitions in the slab cause active release of fluids. Ascension of these fluids leads to decreasing melting temperature above the slab and the origin of diapirs and magmatic chambers (Poli and Schmidt, 1995). In this case, a prominent cluster of events at $\sim 40 \mathrm{~km}$ depth beneath the western boundary of the caldera may delineate the border of an area with high content of molten material beneath Toba.

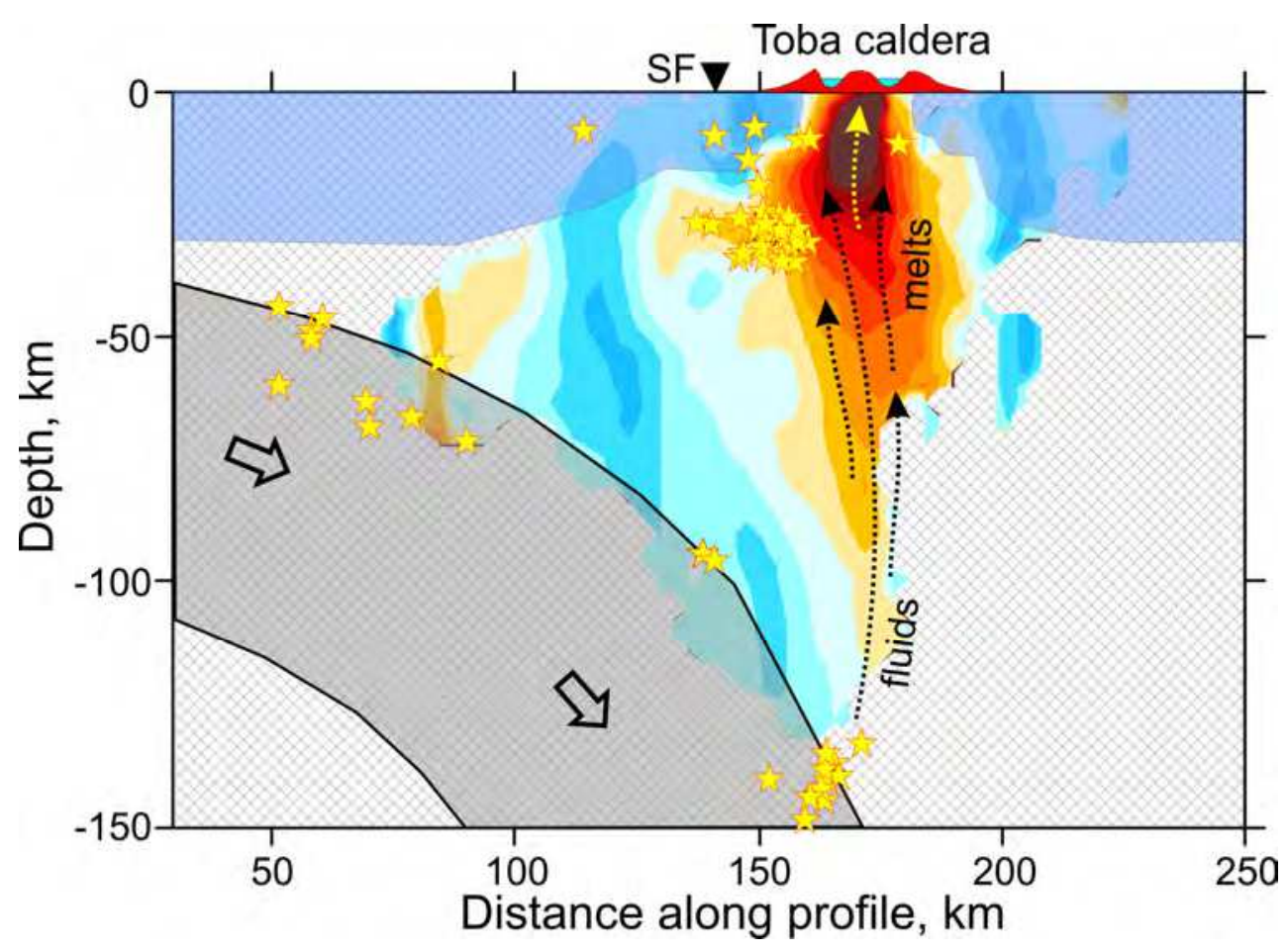

Fig. 10. Interpretation of the results along the vertical profile. Background is the distribution of $P$ velocity anomalies. Yellow stars are the final location of events used in this study. Dotted arrows mark schematically the path of ascending fluids and partially molten material. Black triangle and SF indicates the Sumatra fault.

It is unexpected that beneath Toba we observe moderate values of $\mathrm{P}$ and $\mathrm{S}$ velocity anomalies. At a depth of $5 \mathrm{~km}$ the anomalies reach $16 \%-18 \%$, however they may be partly related to young sediments which filled the Toba caldera. Some anomalies can also be related to fracturing of rocks along the Great Sumatra Fault. When considering only seismic velocities, it is not easy to distinguish these factors from volcano related anomalies (e.g. magma chambers). At $15 \mathrm{~km}$ depth beneath Toba and Helatoba volcanoes we observe anomalies which are slightly stronger than $10 \%$. This is likely a signature of volcanic 
chambers and magma paths, however this value is not higher than observed in normal volcanic areas like Central Java (Koulakov et al., 2007, 2009c) and Central Chile (Koulakov et al., 2006) which will be discussed in next chapters. In the mantle the amplitude of anomalies is less than $7 \%$ that is relatively low for volcanic areas. In this sense, no significant signature of super volcanism is observed here.

Much more interesting features are observed at the distribution of $\mathrm{Vp} / \mathrm{Vs}$ ratio which roughly reflects the content of melts and fluids. Variations of this parameter observed at different depths are much more significant than those of $P$ and $S$ velocity anomalies. At 5 $\mathrm{km}$ depth we obtain dominantly low values of $\mathrm{Vp} / \mathrm{Vs}$ ratio with the value of about 1.62. At the same time, just beneath the presently active volcanoes we observe few local patterns with contrasted $\mathrm{Vp} / \mathrm{Vs}$ ratio anomalies which reach 1.87 . These patterns possibly indicate the magmatic reservoirs which feed the volcanoes. The concept of magma chamber is widely accepted in popular scientific literature (e.g. a typical cartoon in every school book where a volcano is connected with a large spherical body of magma chamber). At the same time, in many fairly robust and high resolution tomographic studies for other volcanoes, the chambers are not clearly detected (see examples in the next paragraphs). Beneath Toba and surrounding volcanoes at shallow depths we observe quite small bodies with extremely high $\mathrm{Vp} / \mathrm{Vs}$ ratio which are quite clear indicators to the magma chambers.

The high $\mathrm{Vp} / \mathrm{Vs}$ ratio patterns are also observed beneath the volcanic arc in the middle and lower crust (15 km and $25 \mathrm{~km}$ depth), where their sizes and amplitudes increase (up to 1.90). For the mantle wedge, the resolution of the $\mathrm{Vp} / \mathrm{Vs}$ becomes rather poor, mostly due to trade-off with source depth and origin times. However, high values of $\mathrm{Vp} / \mathrm{Vs}$ are robustly resolved beneath the Toba caldera in all depth sections. The fact that Vp/Vs contrasts are much more important beneath Toba caldera than $\mathrm{P}$ and $\mathrm{S}$ velocity anomalies is probably an indicator that the observed anomalies are mostly related to melting processes rather than to temperature, chemical or mechanical reasons.

\subsection{Merapi volcano, Central Java}

In this chapter I consider the tomographic studies in the area of Merapi in Central Java which is one of the most active volcanos in the world and represents a tremendous hazard to the local population. Mt. Merapi is a stratovolcano showing evidence of explosive eruptions over the last 7000 years (Newhall et al. 2000) and earlier (Camus et al. 2000). Besides volcano hazard, this part of Indonesia suffers of strong seismic activity. For example, on May 26, 2006 at 22:54:01 UTC a strong magnitude $\mathrm{M}_{\mathrm{w}}=6.3$ earthquake occurred in Central Java, Indonesia about $25 \mathrm{~km} \mathrm{SSW}$ of Yogyakarta (May 27 at 5:54 AM local time in Java, Indonesia) and caused more than 6000 fatalities.

In 2004, combined amphibious seismological investigations have been performed in the framework of the MERAMEX (MERapi AMphibious EXperiment) project to study a volcanic arc system as part of an active continental margin. More than 100 seismic stations were operated continuously for more than 150 days (Figure 11). The local seismicity data recorded at these stations were used to perform a local tomographic inversion (Koulakov et al., 2007). Besides the passive data from local earthquakes, an active source experiment was performed at the same time. The airgun shots along three offshore lines were clearly registered and picked at onshore stations allowing the possibility to combine passive and active data to enhance the resolution in the overlapping area. The results of the combined active and passive data inversion are presented by Wagner et al., (2007). 


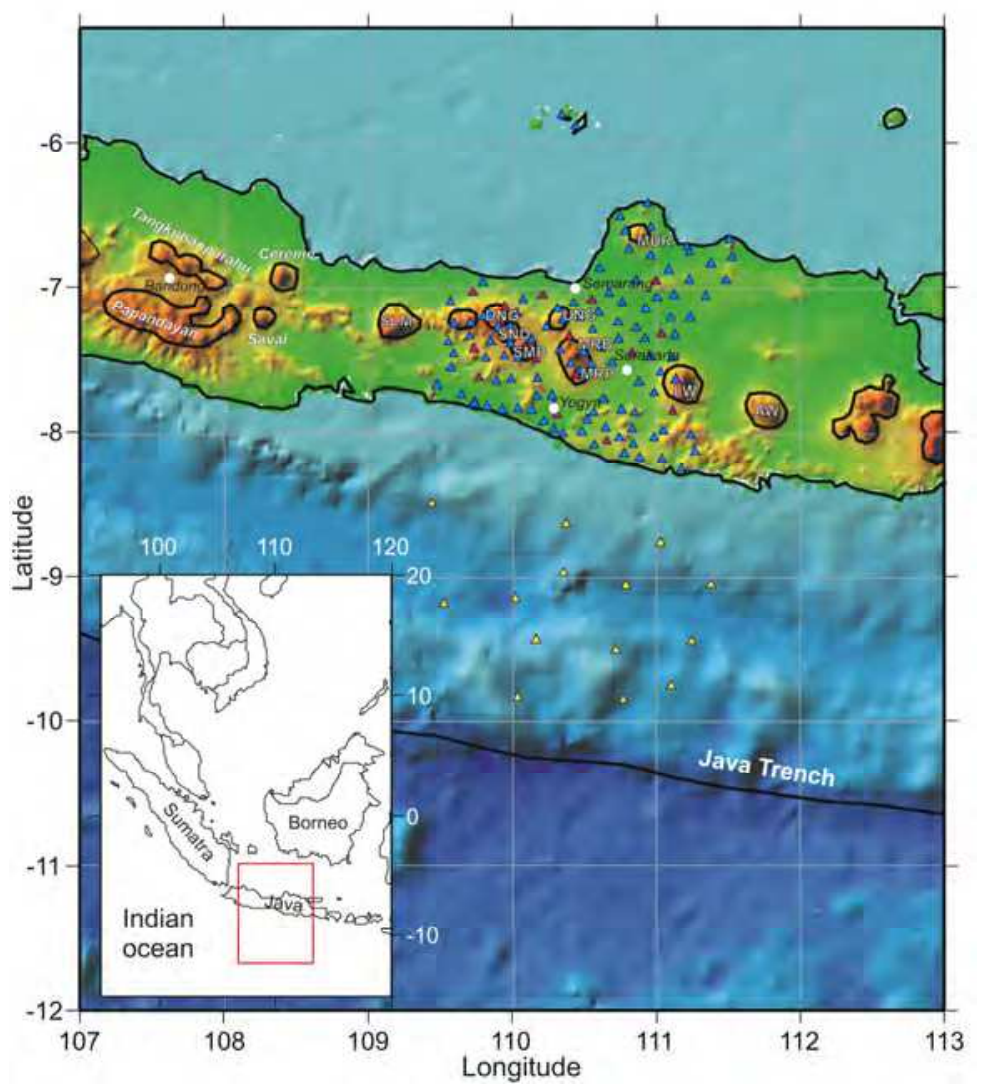

Fig. 11. Relief and bathymetry of the study area. The main volcanic complexes are highlighted with black contour lines. Volcanoes: SLM - Slamet, DNG - Dieng, SND Sundoro, SMB - Sumbing, MRB - Merbabu, MRP - Merapi, MUR - Muria, LW - Lawu, AW Arjuno-Welirang. The main cities are marked with white circles. Triangles show positions of the MERAMEX stations (red: broadband stations, blue: short-period stations, yellow: ocean bottom stations).

The dense ray coverage in this experiment made it possible to implement the anisotropic tomographic inversion for the P-velocity model. An orthorhombic anisotropy with one predefined direction oriented vertically is determined by four parameters in each point. Three of them describe slowness variations along three horizontal orientations with azimuths of $0^{\circ}, 60^{\circ}$ and $120^{\circ}$, and one is a perturbation along the vertical axis. Here I discuss the results of anisotropic inversion which are presented in Koulakov et al., (2009c).

The most important feature at shallow depths (Figure 12) is a strong low-velocity anomaly beneath the middle part of Central Java which is highlighted with violet dotted line. It consists of several segments which appear to be located between the main volcanic complexes. The strongest anomaly is observed between the Lawu and Merapi complexes and called MLA. The amplitude of this anomaly estimated from modeling with realistic patterns is about $-30 \%$. Another anomaly is located between the Sumbing and Merapi 
complexes, and the smallest anomaly is detected between the Sumbing and Slamet volcanoes. Beneath volcanoes we observe local patterns of higher anomalies which probably represent the location of channels or chambers filled with frozen magmatic rocks having higher seismic velocities. It is important that positive velocity patterns are observed beneath dormant volcanoes (e.g. Lawu, Sumbing, Sundoro, Merbabu, Ungaran). Beneath Merapi, the most active volcano in this region, such a feature is manifested less clearly.

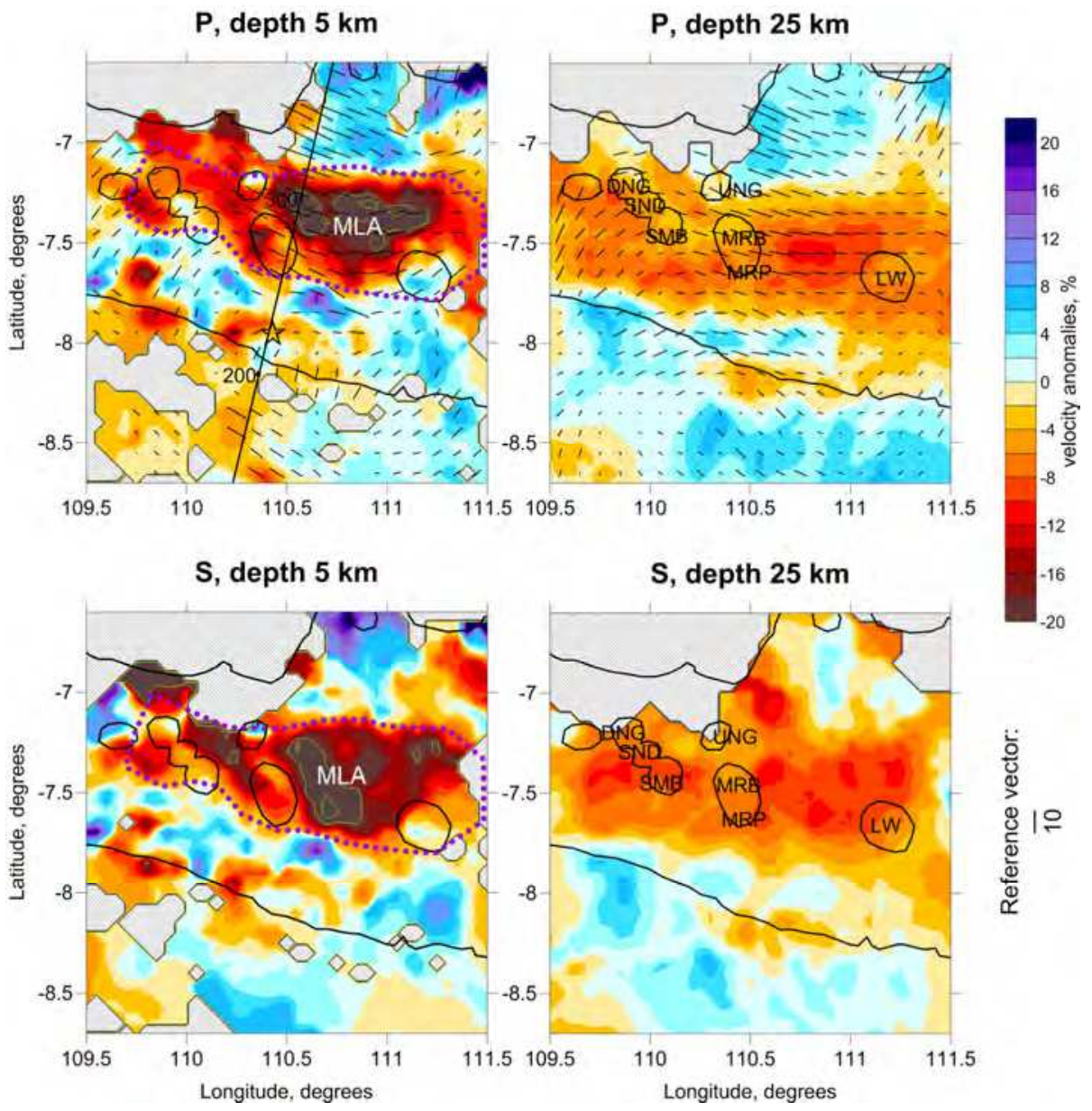

Fig. 12. Anisotropic P- and isotropic S-velocity distributions beneath Central Java in two horizontal sections. Colors indicate the isotropic velocity perturbations; yellow lines within "red" patterns are the contours of $20 \%$ and $25 \%$; bars show directions of fast horizontal P velocities. Length of bars reflects the difference between fastest and slowest horizontal velocities. Position of the cross section presented in Figure 13 is marked in maps corresponding to $5 \mathrm{~km}$ depth. The star shows the hypocenter of Bantul $\mathrm{M}_{\mathrm{w}}=6.5$ earthquake (26.05.2006 UTC). Indications of volcanoes correspond to caption in Figure 11. Violet dotted line highlights the feeding area of volcanoes in Central Java. 
In the forearc, between the coast and the volcanoes, the isotropic velocity structure is strongly heterogeneous. This complex structure can be explained by the presence of high velocity rigid crustal blocks separated with low velocity belts which represent folded areas.

Figure 13 shows the inversion result in a vertical section and presents our qualitative understanding of the link between the tomography results and the manifestation of surface tectonics and volcanism. In this section, an interesting combination of seismic velocity anomalies, anisotropy and seismicity distribution is observed. Beneath Merapi we can see an inclined low velocity anomaly which links the volcano with the seismicity cluster at 110-130 $\mathrm{km}$ depth marked by a pink ellipse in Figure 13A. This cluster can be explained by phase transitions and melting in the downgoing slab that cause significant fluids release (e.g. Poli and Schmidt, 1995). These fluids move upward (blue arrows in Figure 13), and decrease the melting temperature in the overlying mantle and crust. This might cause ascent of diapirs which reach the Earth surface and cause the origin of volcanism. We propose that the observed low-velocity anomaly represents the paths of migration of fluids ascending from the subducted slab. The natural question is why fluid migration does not occur vertically, as in the case of Toba Caldera (see previous chapter), but along an inclined zone with an angle of about $45^{\circ}$. Actually, several different processes (mechanical ascend due to Archimedes forces, corner flow, melting and chemical reactions) coexist in the mantle wedge. Summary effect of such multi component system is hardly predictable. One of the possible explanations can be an effect of drift of the ascending fluids and melts by corner flow in the mantle wedge.

The tomographic results show that crust and upper mantle beneath Central Java appear to be strongly anisotropic. The average magnitude of anisotropy is about $7 \%$; however, due to uncertainty of damping determination and trade-off between isotropic and anisotropic parameters, these values should be interpreted with prudence.

In the crust beneath Central Java different anisotropic regimes are observed (Figure 12, left column). In the forearc between the southern coast of Java and the volcano chain the anisotropic properties seem to be chaotic and relatively weak: all directions of fast velocities coexist within this relatively small area. Variety of anisotropy orientations is a clear indicator to complex crustal structure in the forearc. This is also supported by mosaic structure of isotropic velocity anomalies. Note that the main patterns are similarly visible in $\mathrm{P}$ and $\mathrm{S}$ models computed independently. The strongest horizontal anisotropy in the crust is observed within a large low-velocity anomaly between Merapi and Lawu volcanoes (MLA). Inside this anomaly we observe an east-west trending of faster velocities, and the amplitude of anisotropy reaches $10 \%$. In the vertical section (Figure 13B) we observe clear separation according to character of the vertical anisotropy. Beneath the volcanoes, in the southern part of MLA, faster vertical velocities are observed, while in the northern part, where maximal amplitudes of velocity anomalies were found (30-35\%), the anisotropy tends to be horizontal. For the volcanic areas, we suppose that fast vertical velocities and arc parallel trending of horizontal anisotropy can be caused by existence of vertical dykes and channels beneath the volcanoes. Such structure with elongated vertical fine features causes higher effective velocity in vertical direction which is detected in the anisotropic results. Horizontal trending of anisotropy in the northern part of the MLA which is seen in the vertical section (Figure 13B) is probably due to layering of sediments in the uppermost part. Additionally, we suppose that it may be also due to penetration of horizontally oriented intrusions. Very low velocities in MLA and strong attenuation of $S$ velocities are possible indicators that these intrusions are filled with molten magma. Another indirect argument for this 


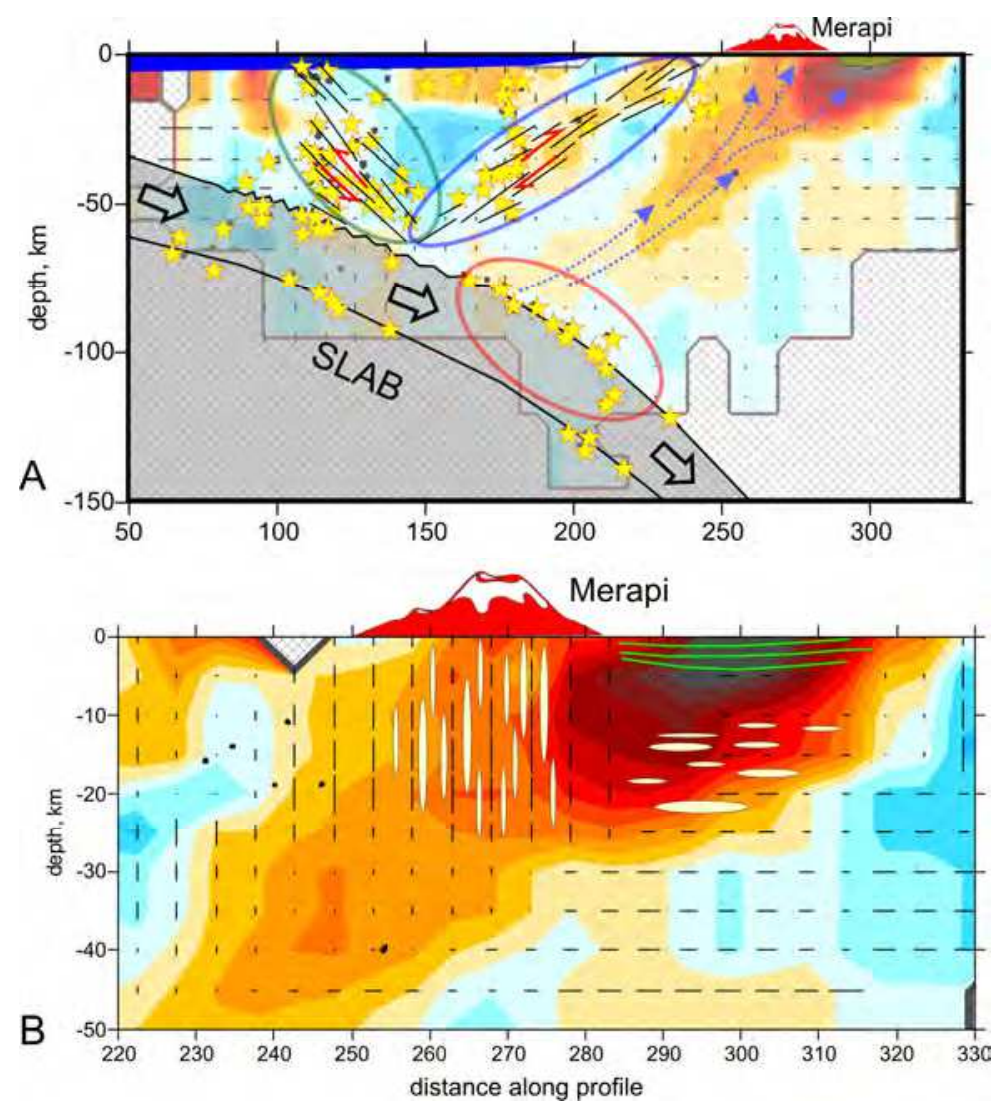

Fig. 13.a. Interpretation of the results. The background is the result for $\mathrm{P}$ velocities along the profile shown in Figure 12. Yellow stars show distribution of local seismicity recorded within this study. The pink ellipse highlights the events in the slab at $110 \mathrm{~km}-130 \mathrm{~km}$ depth which could be related to phase transition and fluid release from the slab. Dotted blue arrows indicate schematic distribution of released fluids and partial melting zones according to our interpretation. Blue and green ellipses highlight the events which could be related to thrusting caused by increasing of the friction rate on the slab upper surface. Shallow green area to the right of Merapi indicates the sediment cover above the MLA. Black strokes above the slab indicate possible areas with maximum stress concentration. $\mathrm{B}$.) Zoom for the area beneath Merapi volcano. Elongated ellipses show schematically distribution of channels, dykes and lenses filled with magmatic material. Green lines indicate schematically sediment layers.

hypothesis is large level of remnant residuals for the stations located within MLA. These unexplained residuals can be due to small high contrasted patterns (magma pockets) which are below the resolution capability of the inversion algorithm, but still affect the travel times. As for strong anisotropy in MLA observed in the map view, we believe that it can be controlled by the regional stress regime. Deviatoric stresses induce preferential opening and closing of cracks, potentially introducing seismic anisotropy in rocks. These effects are 
especially evident in cracked porous media (Gibson and Toksoz, 1990) as expected in MLA, where a lot of thermal fields are observed. In the case of tectonic deformations, fast seismic velocities are observed parallel to compressional stress direction (e.g., Lees and $\mathrm{Wu}, 1999$ ).

For the deeper section, the horizontal orientation of fastest velocity axes seems to be fairly regular. At a depth of $25 \mathrm{~km}$ and deeper, which correspond to the uppermost mantle, the anisotropy beneath the coastal area is oriented parallel to the trench and roughly perpendicular to the direction of subduction. We explain the trench-parallel anisotropy in the mantle wedge by presence of B-type olivine (Jung and Karato 2001). This fabric is generated in special conditions which presume presence of water and melts. The tomographic results show an inclined low-velocity anomaly which connects the seismicity cluster at the depth of about $100 \mathrm{~km}$ with the active volcanoes on the surface (Figure 13). We interpret this anomaly as path of fluids which are released from the slab due to phase transitions. These fluids may initiate active melting in the mantle wedge and in the crust beneath the volcanoes. Both fluids and melts may take part at producing B-type olivine with orientation of the fast axis perpendicular to the flow direction.

In general the anisotropic tomographic study has provided a rich material for understanding the deep sources of feeding Merapi and other volcanoes of Central Java. The most important finding is a huge MLA anomaly with the amplitude of about $30 \%$. At the same time, beneath the volcanoes we did not find any features which could be interpreted as magma chambers. So the classical concept of a large reservoir filled with liquid magma, which is often shown in popular and school books, is not valid for this case. However, the resolution of the tomographic model may appear to be not sufficient to resolve such a feature. To give a definitive answer about the existence of magma chamber, more dense networks around volcanoes are required.

\subsection{Central Andes: Multiple paths of the arc feeding}

The Andes are one of the largest active mountain ranges in the world, extending for over $8000 \mathrm{~km}$ along the western edge of South America (Figure 14). The subduction of the Nazca plate at a rate of about $8.4 \mathrm{~cm}$ /year (relative to South America (DeMets et al., 1990) under the South American continent has been going on for more than 200 Myr. The crustal structure of the Central Andes was influenced by the eastward migrating magmatic arc (Scheuber et al., 1994) due to strong erosion of the upper plate lithosphere in the subduction zone. This migration is expressed by a $200 \mathrm{~km}$ shift of the volcanic arc system to the east since the early Jurassic. Today the main volcanic arc is located along the Western Cordillera. The forearc region can be subdivided into four main morphological units from west to east (Figure 14): (1) Coastal Cordillera coinciding with the position of the volcanic arc in Jurassic times; (2) the Longitudinal Valley located at the place of the Jurassic back arc basin and the Mid-Cretaceous magmatic arc; (3) Precordillera located on the late Cretaceous magmatic arc; and (4) the Preandean depression containing the Salar Atacama block and bordered from the east by active volcanoes.

In the framework of the multidisciplinary international project SFB 267 several arrays of portable seismic stations were installed between $20^{\circ} \mathrm{S}$ and $25^{\circ} \mathrm{S}$ from the Pacific coast across the Andean mountain range (Figure 14C) in the time period from 1994 to 1997. In total, more than 100 seismic stations recorded about 1500 deep and crustal earthquakes and about 50 000 rays. This dataset was processed by several researchers and their results were published 
in many papers. Shurr et al., (1999) performed the preliminary location of sources and found the optimal 1D model. The results of travel-time tomographic inversion were presented as a PhD thesis by Schurr (2001). More than 15000 values of $t^{*}$ were inverted, and the corresponding model of P-wave attenuation was presented by Schurr et al., (2003) and Haberland et al., (2003). Koulakov et al., (2006) revised the same dataset and presented new models of $\mathrm{P}$ and $\mathrm{S}$ velocities, $\mathrm{Vp} / \mathrm{Vs}$ ratio and $\mathrm{Qp}$ attenuation based on inhomogeneous 3D starting velocity model.
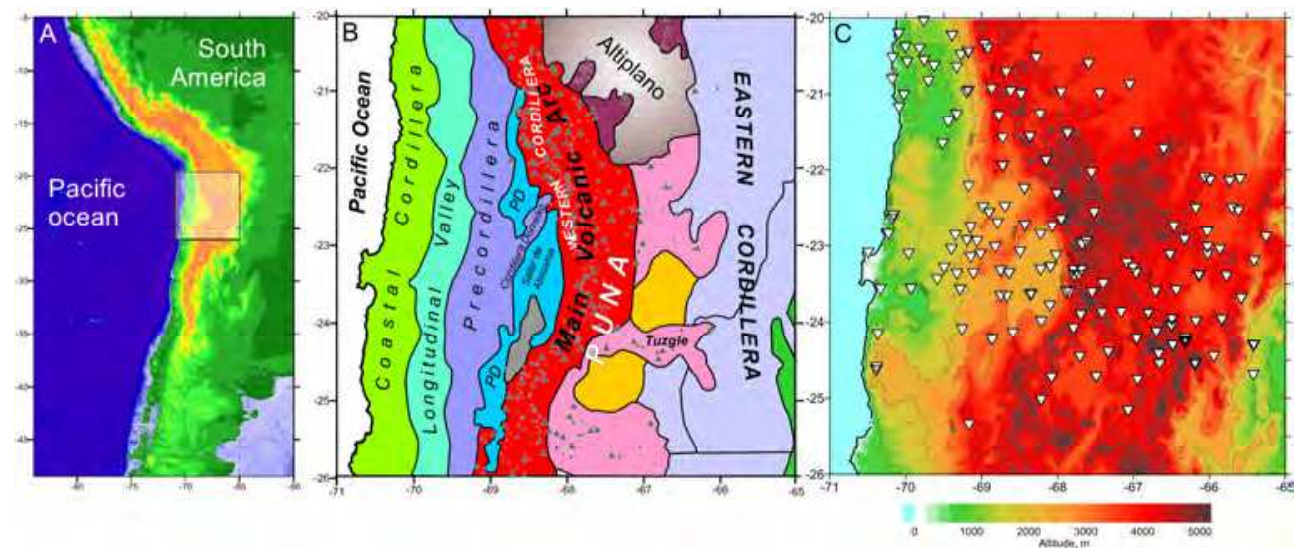

Fig. 14.a. Position of the study region in South America marked by rectangle. B: Simplified map of the main tectonic elements shown with different colors. PD: Preandean depression; APVC: Altiplano-Puna volcanic complex. The position of recent volcanoes (up to 5Ma) from the catalogue by de Silva \& Francis, (1991) is shown by triangles. The size of the triangles reflects volume of the volcanoes. C: Smoothed topography and the distribution of seismic stations used for the inversion.

Here I present the most recent model constructed with the use of the LOTOS code (Koulakov, 2009a). The inversion results for $\mathrm{P}$ and $\mathrm{S}$ velocity anomalies are shown in horizontal and vertical sections in Figure 15. These new results show the link with the main geological structures much clearer than previously published models. At $25 \mathrm{~km}$ depth, we can see a very clear separation between high-velocity forearc and low-velocity volcanic arc. It was found that in Jurassic time the arc was located in the area of present location of Coastal Cordillera. After this time, the arc was replaced to more than $200 \mathrm{~km}$ due to erosion of the continental plate by the subducted lithosphere. Thus, the area between the coast and volcanic arc is composed of rigid igneous rocks erupted during eastward migration of the subduction complex. These strongly consolidated rocks are expressed as high-velocity patterns. Inside the high-velocity zone, we can distinguish several blocks which are visible in geological map (Figure 14B). For example, Salar de Atacama block is clearly separated from the Preandean Depression. Cordillera Domeiko, which marks the previous location of the volcanic arc, is expressed by locally lower velocities.

The crustal structure beneath the backarc appears to be more complex. Although, lowvelocities dominate there, we do not observe direct correlation between seismic structures and the distribution of backarc volcanoes. On the contrary, in the mantle (below $70 \mathrm{~km}$ 
depth) a clear low-velocity anomaly is located beneath the Tuzgle volcano complex. Based on these results we can conclude that the origin of the backarc volcanism of the Tuzgle complex is significantly different of that of the arc volcanism. Beneath Tuzcle, the mantle seems to be overheated, and the volcanoes produce high-temperature and dry magmas. Beneath the arc, the temperature in the mantle wedge is normal, but high content of fluids lowers the melting temperature. As a result, the magma products in arc volcanoes are of lower temperature, but rich with fluids.
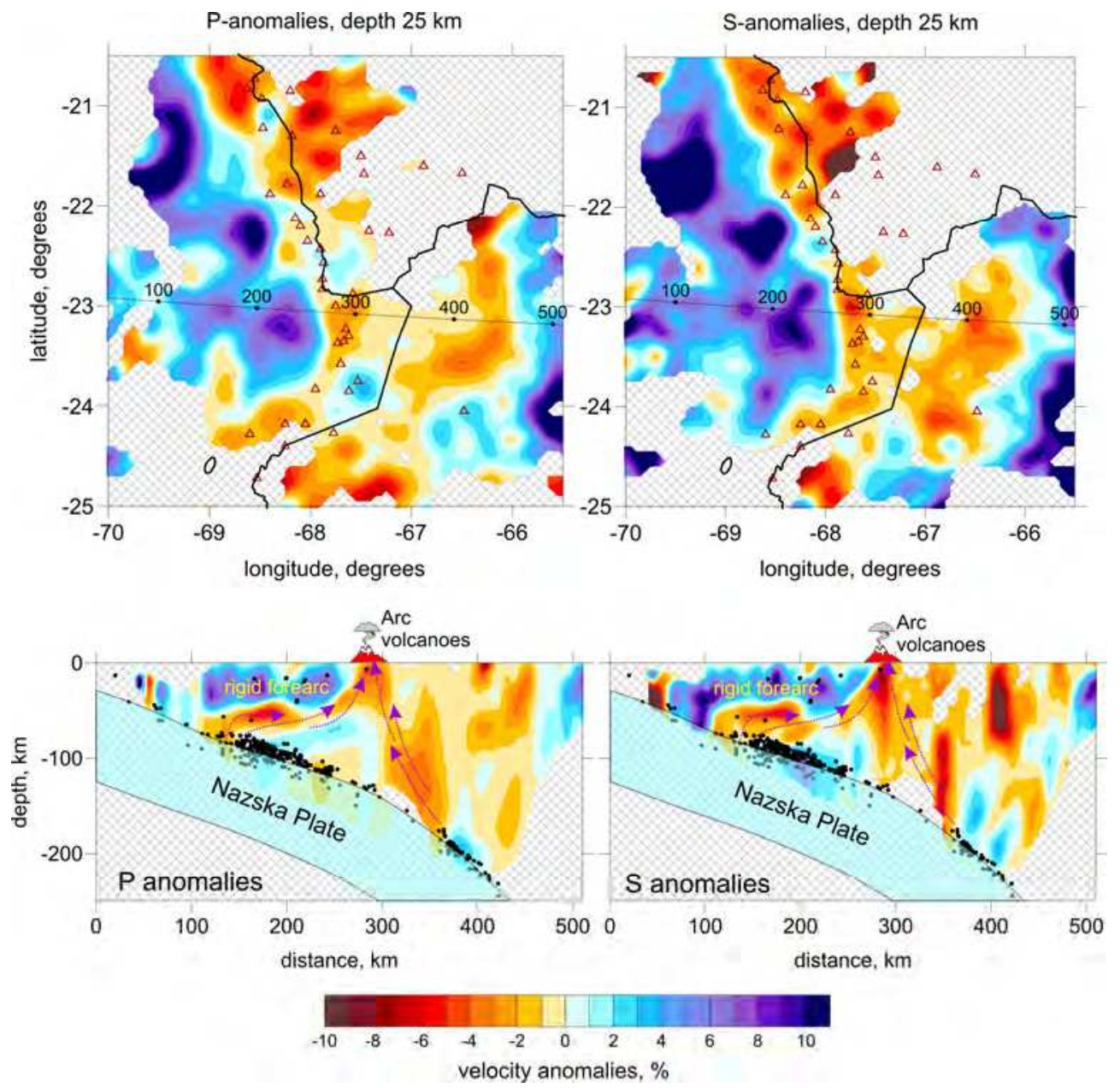

Fig. 15. P and S-velocity anomalies beneath Central Andes at $25 \mathrm{~km}$ depth and in a vertical section. Location of the profile is indicated in maps. Triangles in maps depict the locations of recent $(1 \mathrm{Ma})$ volcanoes. Black dots in vertical sections are the locations of earthquakes at distances of less than $20 \mathrm{~km}$ from the profile. Violet dotted arrows indicate hypothetical migration of fluids from the slab. 
The paths of feeding the arc volcanoes can be seen in vertical sections in lower row of Figure 15. It can be seen that the deep seismicity clearly delineates the upper boundary of the subducting slab. We observe two clusters: around the levels of 100 and $200 \mathrm{~km}$ depth. Between these clusters we see a clear gap. It is interesting that both in P and S-velocities, these clusters seem to be linked with the volcanic arc through low-velocity patterns. We propose that both of these clusters are due to phase transitions on the subducting slab which cause the release of fluids (Poli \& Schmidt, 1995). In the case of the upper cluster at $100 \mathrm{~km}$ depth, the fluids ascend upward, but meet the bottom of the rigid forearc block. Then they migrate eastward and reach the surface at the eastern border of the forearc, where the present arc is located. Another cluster seem also to produce some fluids which also ascend, but with a westward bias. These fluids reduce the melting temperature of rocks in the mantle wedge and in the crust. The melting products are delivered to the volcanoes of the arc. Note that the trenchward orientation of the fluid path appears to be different of that observed beneath Merapi volcano in Central Java and Toba in Sumatra.

\subsection{Kluchevskoy volcano group: Multi-level feeding determines the variety of eruption regimes}

In subduction zones, the volcanic arcs are represented by complex distribution of volcanoes of considerably different eruption regimes and magma compositions. One of the brightest examples of volcano variability within one local complex is the Kluchevskoy volcano group located in Kamchatka Peninsula (Russia). In this chapter, I present results of tomographic inversion for seismic crustal structure beneath the Kluchevskoy group that were recently published by Koulakov et al., (2011a).
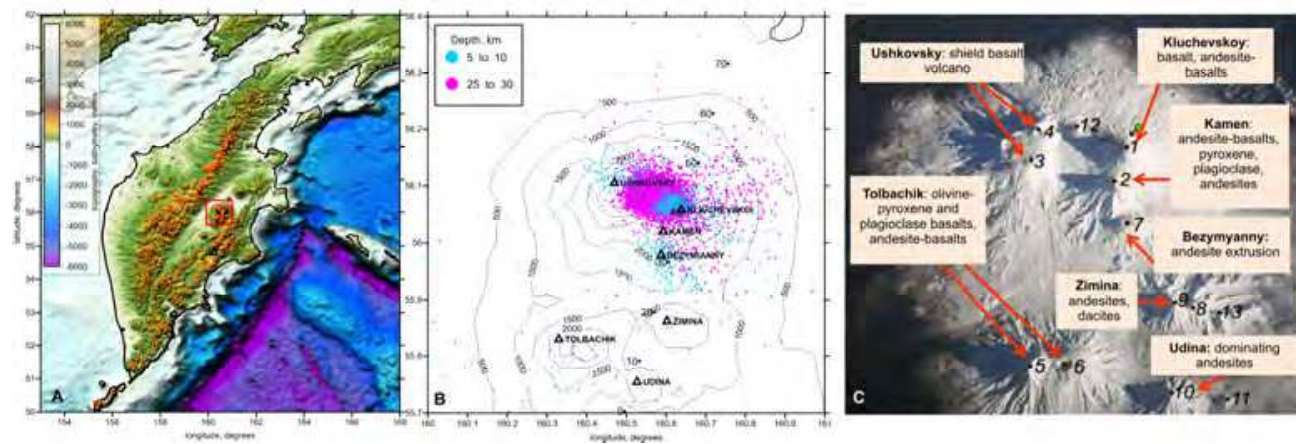

Fig. 16. Kluchevskoy Volcano Group: location, data distribution and information on volcanoes. A: Topography and bathymetry of the Kamchatka Peninsula. Red dots depict Cenozoic volcanoes; red rectangle marks the study area. B: Location of seismic stations (blue diamonds) and events in two depth intervals (colored dots). C: Satellite image and general information on volcanoes of the Kluchevskoy Group.

The Kluchevskoy volcano group covers an area of about 100x60 km size and includes 13 active and dormant volcanoes. Three of them, Kluchevskoy, Tolbachik and Bezymyanny, are some of the most productive and intensive volcanoes of the world. Kluchevskoy 
volcano, which is about 4800 meters high, is the largest active volcano in continental Eurasia. The composition and the activity regimes within the Kluchevskoy group (Figure 16C) vary very strongly from explosive andesitic to fissure basalt Hawaiian type eruptions (e.g., Fedotov et al., 2010). Furthermore, there are some evidences that, in some volcanoes of the group, the regimes and composition of eruptions might abruptly change during a relatively short periods of time (Laverov, 2005). For example, the major products of current eruptions of the Kluchevskoy volcano consist of the high-alumina basalts, (Khrenov et al., 1989), while older lavas consisted of high-magnesium basalts with up to $12 \% \mathrm{MgO}$ and rocks of intermediate composition (Ozerov et al., 1997). The Kluchevskoy volcano acts with moderate eruptions alternated with silent periods lasting several years (Ozerov et al., 2007, Ivanov, 2008). The other volcanoes of the group are strongly variable in composition and activity regimes (Laverov, 2005). Bezymianny, which is located at about ten kilometers from Kluchevskoy, is an explosive andesite volcano with magmas containing 54.5 to $62.5 \%$ of SiO2 (Gorshkov and Bogoyavlenskaya, 1965, Ozerov et al., 1997). Before the years of fifties of the last century, Bezymyanny («Nameless », in Russian) was not considered as an active volcano. The catastrophic eruption in 1955-1956 which ejected more than five cubic kilometers of rocks was one of the largest volcanic events in twentieth century. The dormant Udina volcano, located in the southeastern part of the group, is composed of alternating lavas and pyroclastic layers consisting of basalts and andesites (Laverov, 2005). Zimina is a complex of three dormant stratovolcanoes consisting of andesite extrusions, dacite and basalts lavas (Braitseva et. al., 1994). The Ushkovsky volcano, located in the northwestern side of the Kluchevskoy group, has a very complex structure (Braitseva et. al., 1994). Initially, it was constructed as a shield volcano of the Hawaiian type and consisted primarily of basaltic lavas. In more recent stages, a series of stratovolcanoes appeared that consist of alternating pyroclastic andesite-basalts and lavas of similar composition (Laverov, 2005). Finally, the Tolbachik complex, located in the southwestern part of the Kluchevskoy group, contains several shield and stratovolcanoes of very different structures and compositions. The presently active Plosky Tolbachik volcano is a typical Hawaiian-type volcano with fissure eruptions and calderas. The fissure type eruption of Tolbachik in 1975-1976 appears to be the largest historical basalt eruption in Kamchatka (e.g., Fedotov et al., 2010). This diversity of composition and eruption regimes in volcanoes at distances of dozens of kilometers from each other shows that their feeding occurs both directly from mantle sources and through complex system of intermediate chambers in the crust (e.g., Khubunaya et al., 2007).

Another feature of this region which is very important for tomographic inversion is the major part of seismic energy is released at great depths (Figure 16B). Most seismic events occur at depths between 23 and $28 \mathrm{~km}$. This enables favorable illumination of the crustal structures by seismic rays and creates better conditions for tomographic inversion compared to most other volcanoes, for example, Etna (Patanè et al., 2006). It is interesting that the depth distribution of seismicity over time seems to correlate with major eruptions of the Kluchevskoy volcano. During the activity periods, the seismicity clusters tend to be shallower.

The particular behavior of the Kluchevskoy group might be caused by its location near the junction of the Kuril-Kamchatka and Aleutian subduction zones (Figure $16 \mathrm{~A}$ ) which is considered by many authors as a singular point with unusually active geodynamical 
processes. According to the distribution of deep seismicity and the results of regional and global tomographic studies (e.g., Gorbatov et al., 2001, Bijwaard et al., 1998, Koulakov et al, 2011b), between the Kuril-Kamchatka and Aleutian slabs there is a clear gap which is seen as a low-velocity anomaly. The horizontal distance from the Kluchevskoy volcanic group to the edge of the subducting Pacific plate is less than $100 \mathrm{~km}$, whereas the vertical distance to the upper surface of the plate is approximately $150 \mathrm{~km}$. This unique location above the end of the subduction zone may cause mantle flows that control a specific activity of the volcano group.

The tomographic inversion by Koulakov et al., (2011a) was based on data provided by the Kamchatka Branch of the Geophysical Survey of the Russian Academy of Sciences. The available dataset includes half millions travel times from about 80000 local earthquakes in the area of the Kluchevskoy volcano group recorded by seventeen permanent seismic stations in a time period from 1999 to 2009. The events are widely distributed in space, and most of them are located below $25 \mathrm{~km}$ deep, which provides good ray coverage for studying the crustal structure beneath the volcanoes. In addition, for most events, both $\mathrm{P}$ and $S$ phases were handpicked by highly experienced specialists. The use of approximately equal numbers of $\mathrm{P}$ and $\mathrm{S}$ phases enables the determination of high quality source locations.
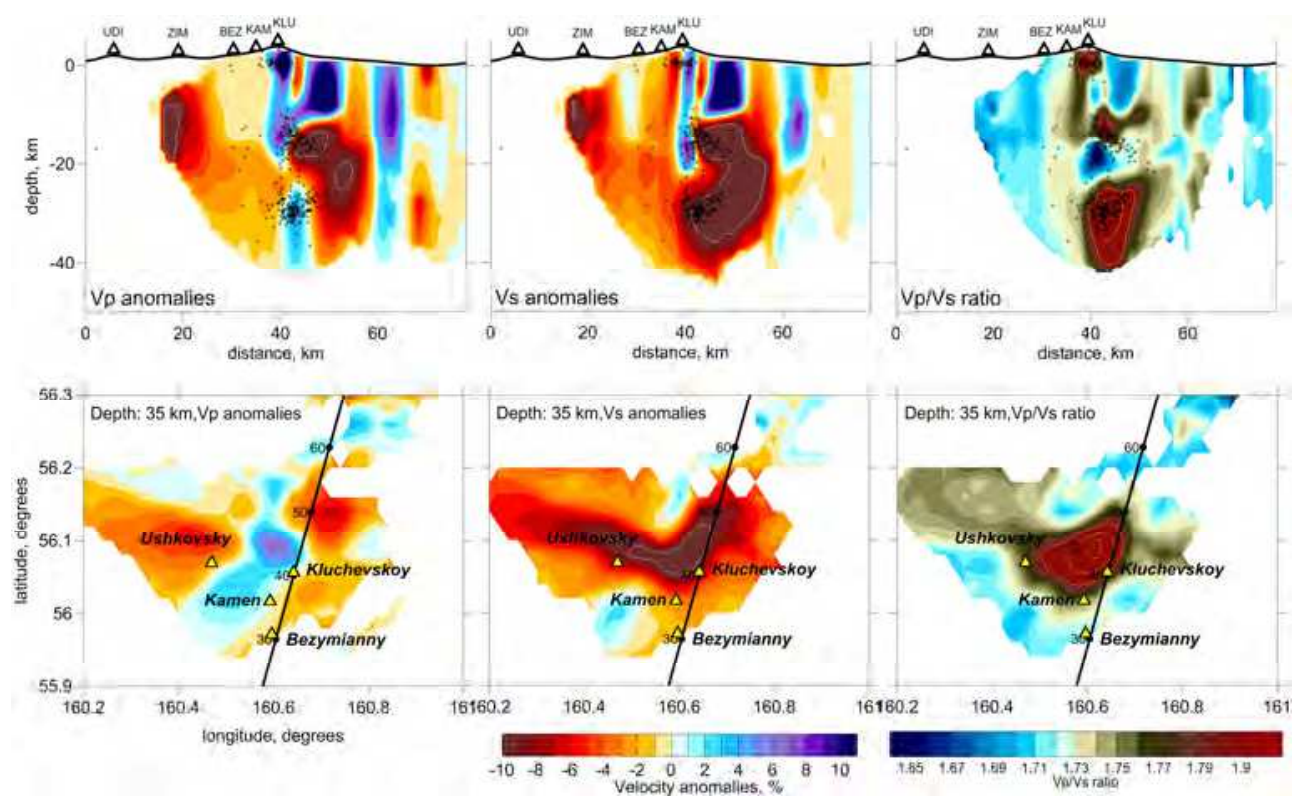

Fig. 17. P and $\mathrm{S}$ velocity anomalies and $\mathrm{Vp} / \mathrm{Vs}$ ratio beneath the Kluchevskoy Volcano Group presented in vertical (upper) and horizontal (lower) sections. Location of the profile is indicated in maps. Black dots represent seismicity nearly the vertical section. Volcanoes are show by triangles above the vertical section plots.

Approximately same dataset has already been used by other authors in (Nizkous et al., 2006, Khubunaya et al., 2007) where they report the distribution of P velocity beneath the 
Kluchevskoy group. We have also performed the inversion for the full dataset and obtained rather similar results as in the previous studies. However, a rather low value of variance reduction (about 15\%) makes us to doubt in robustness of this solution. This means that it is hardly possible to build a single model which satisfies all the data for more than ten years. Koulakov et al., (2011a) performed the inversion for one year in 2004 and obtained much more robust solution than in the case of the entire data inversion. This fact indirectly shows strong variability of seismic structure beneath Kluchevskoy volcano group over time.

Here I present the result of inversion for the year 2003 in vertical and horizontal sections (Figure 17) which look rather similar to the results presented by Koulakov et al., (2011a) corresponding to 2004. The most prominent feature of the obtained seismic structure is a large anomaly located beneath the Kluchevskoy volcano at depths below $25 \mathrm{~km}$. In this pattern, we observed positive P-velocity and negative S-velocity anomalies that result in very high $\mathrm{Vp} / \mathrm{Vs}$ ratios, reaching 2.2. Very high $\mathrm{Vp} / \mathrm{Vs}$ ratio below $25 \mathrm{~km}$ depth can be explained by both compositional and rheological properties of rocks. The P-velocity is more sensitive to the composition, and its higher values may be an indicator of rocks that came from lower depths. At the same time, very low values of the S-velocity indicate a high content of fluids and partial melting. We interpret this pattern as the top of a small plume (red area in Figure 20) that probably starts on the upper surface of the slab and reached the bottom of the crust. Active seismic clusters were observed within this high Vp/Vs anomaly only above $\sim 30-35 \mathrm{~km}$ in depth. These depths correspond to the lowermost parts of the crust, whose thickness reaches the values of about $30-35 \mathrm{~km}$, based on the results of receiver function analysis (Nikulin et al., 2010). We propose that these earthquakes in the lowermost crust, which fit to high values of $\mathrm{Vp} / \mathrm{Vs}$, mark the first level of magma storage between 25 and $30 \mathrm{~km}$ in depth. The seismicity at this level is probably due to strong thermal, chemical and mechanical effects of the ascending flow in the mantle channel which reaches the brittle crust.

The distribution of seismicity and velocity patterns in the crust forms a regular pattern which is marked in Figure 18 with S-shaped orange arrows. This cluster might indicate the paths of fluids and melts that ascend from the deep magma source at $25-30 \mathrm{~km}$ in depth to Kluchevskoy volcano at the surface. At intermediate depths between $\sim 10$ and $15 \mathrm{~km}$ beneath the Kluchevskoy volcano, we observed another anomaly of high $\mathrm{Vp} / \mathrm{Vs}$ ratio, which probably marks the second level of magma storage. Clear records of shear waves do not support an idea of the existence of large chambers filled with liquid magma. We propose that these zones of high $\mathrm{Vp} / \mathrm{Vs}$ ratio represent either sponge-structured areas with small blobs of partially molten material, or fracturing zones with systems of cracks filled with fluids and/or melts. In any case, these zones should play an important role in feeding the volcano system. Here, the magma migration can cause fracturing of crustal rocks, mixing and differentiation of molten material in magma storages. Thus, the properties of magma in these intermediate chambers might be considerably different from those of the initial magma sources in the lowermost crust. The coexistence of deep and intermediate sources can explain the compositional variability of the eruption products of the volcanoes of the Kluchevskoy group.

Just beneath the Kluchevskoy volcano, we observed another shallow anomaly with a high $\mathrm{Vp} / \mathrm{Vs}$ ratio, which might reflect the existence of a third level of magma storage just beneath 
the volcano. This small pattern coexisting with shallow seismicity probably represent the third level of magma storage which is directly responsible for eruption of the Kluchevskoy volcano.

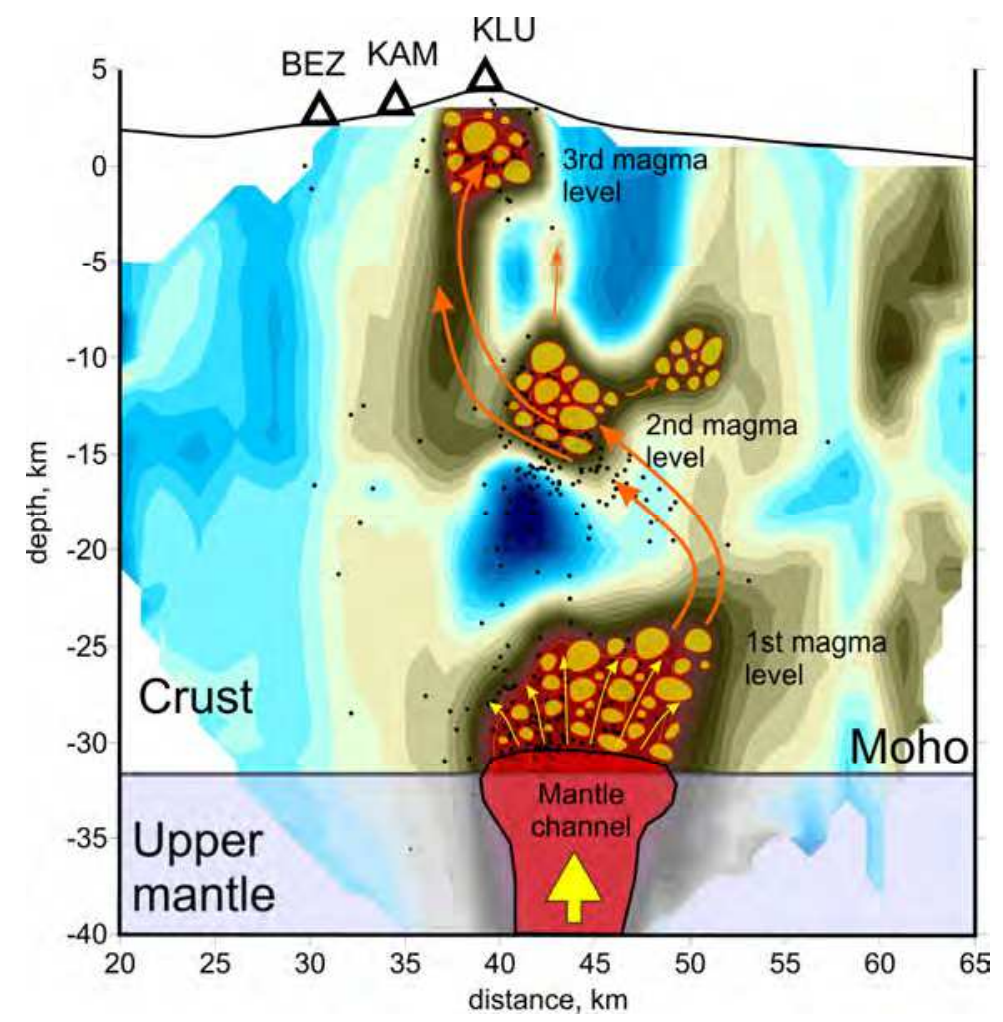

Fig. 18. Interpretation of the results of tomography inversion for the Kluchevskoy volcano group. The background is the distribution of the $\mathrm{Vp} / \mathrm{Vs}$ ratio in the vertical profile (Figure 17). The dots indicate the distribution of earthquakes. The red area in the mantle depicts the main feeding channel that transports upward partially molten deep mantle material. Blobs in the crust that coincide with areas of high $\mathrm{Vp} / \mathrm{Vs}$ ratio mark three levels of magma chambers in the crust. Orange arrows indicate possible paths of magma transport.

The existence of several layers of magma storage beneath the volcanoes of the Kluchevskoy group can explain their different composition and eruption behavior. When overheated liquid material of deep chambers reaches the intermediate depth reservoirs, mixing with crustal rocks, differentiation and decompression result in a very wide variety of magma composition and a high content of fluids and gases. These intermediate magma storages may feed, for example, Bezymianny, which is a caldera-forming explosive dacite-andesite volcano (Bogoyavlenskaya et al., 1991). On the other hand, Kluchevskoy and Kamen 
volcanoes are basalt stratovolcanoes that are feed directly from the deep magma storages. This is consistent with the results of petrochemical analysis by Ozerov et al., (1997) who observed different feeding regimes of Kluchevskoy and Bezymyanny volcanoes through direct channels and intermediate chambers, respectively.

All presented results of detailed tomographic studies in volcanic areas show that each volcanic complex appears to be particular and quite different of others. It shows that shallow structures which are directly responsible for volcano eruptions are in a close link with deep processes extending down to hundreds kilometers depth. It is worth noting that most of volcanic systems are very dynamic, and considerable changes of seismic parameters may occur during years, months and even days. We propose that some of the most important factors which control these changes are variations of stresses and defornations, as well as fast fluid migration.

\section{Conclusions}

In this chapter I made an overview of recent multiscale studies by seismic tomography related to volcanoes. I do not pretend presenting all variety of different approaches and results. Most of the presented models were produced and published in collaboration with colleagues from different scientific centers. A multiscale look to the volcanic systems allows us to reveal some common and particular features in different regions.

In case of intracontinental volcanism, all manifestations of Cenozoic magmatism are related to low-velocity seismic anomalies in the uppermost mantle. In Europe, the distribution of all known Cenozoic basaltic fields, such as French Massif Central, Rhine and Bohemian Massifs, Pannonian basin, well correlate with anomalous zones below the Moho interface. At the same time, neither in our works, nor in tomographic studies by other authors, no clear evidences of mantle plumes, thin contrasted channels, were revealed. Although, lowvelocity anomalies are observed in most cases, their lateral size is compatible with height. Such pattern cannot be called plume. It can represent overheated zones either around a plume or in areas of ascending convective flows in the mantle. It should be noted that incapacity of tomography to reveal clear traces of the mantle plumes might be due to fundamental problems of the method. Even in cases of very high data density, as in the case of Europe, the seismic rays pass around contrasted low-velocity anomalies and accumulate very few information about it. So the plumes are fundamentally very hard objects to detect with tomography, and their robust studying is hardly possible. That is why, even having a lot of data in Europe, we still cannot answer a question if the volcanic fields are attributed to plumes or to ascending convective flows. Same conclusion can be made for two other considered areas, Southern Siberia and Eastern Africa, where the data coverage is poorer than in Europe.

In contrast to the plume-related volcanism, the arc volcanism processes in subduction complexes can be studied in details by seismic tomography thanks to favorable coverage of rays generated by deep seismicity. Examples presented in this chapter show different cases of the slab-arc interaction in various subduction zones. It was shown that the volcanoes of the arc appear to be connected through low-velocity patterns with seismicity clusters in the slab. At the same time, the configurations of these links, as well as depth of seismicity clusters in the slab, are considerably different. 
In this chapter I have underlined the capacity of some tomographic schemes for studying the sources of volcano activity in different areas on different scales. The information derived from tomographic inversions should be considered in a multidisciplinary context together with various geological, geophysical and geochemical data. Note that tomography is a very young method which still is actively developed. This gives us a hope that in the future we will see much more detailed images of deep processes beneath volcanoes than those presented in this chapter.

\section{Acknowledgments}

This study is supported by the Helmholtz Society and RFBR Joint Research Project 09-0591321-SIG a, Multidisciplinary Projects SB RAS \#21, and Project ONZ RAS \#7.4.

\section{References}

Aki, K., Christoffersson, A., Husebye, E.S., (1977). Determination of the three-dimensional seismic structure of the lithosphere. J. Geophys. Res. 82, 277-296.

Aoki Y., M. Takeo, H. Aoyama, J. Fujimatsu, S. Matsumoto, H. Miyamachi, H. Nakamichi, T. Ohkura, T. Ohminato, J. Oikawa, R. Tanada, T. Tsutsui, K. Yamamoto, M. Yamamoto, H. Yamasato, and T. Yamawaki. (2009). P-wave velocity structure beneath Asama volcano, Japan, inferred from active source seismic experiment. J. Vol. Geo. Res., 187:272-277, 2009.

Ashepkov I.V., Yu.D.Litasov and K.D.Litasov, (1996). Xenolites of granet peridotites from melanevelinit of the Khantey range (Southern Zabaikalie): evidences for the mantle diapir upwelling, Russ Geol. Geophys., v. 37, n. 1, P. 130-147.

Bachmann O. \& G. Bergantz, (2008). The Magma Reservoirs That Feed Supereruptions, Elements, 4(1): 17 - 21.

Bell, K., F. Castorina, G. Lavecchia, G. Rosatelli, and F. Stoppa (2004), Is There a Mantle Plume Below Italy?, Eos Trans. AGU, 85(50), doi:10.1029/2004EO500002.

Bell K, Castorina F, Rosatelli G, Stoppa F. (2006). Plume activity, magmatism, and the geodynamic evolution of the eastern Mediterranean. Annals of Geophysics, 49/1, 357-372. ISSN: 1593-5213.

Benoit, M.H., Nyblade, A.A., VanDecar, J.C., (2006). Upper mantle P-wave speed variations beneath Ethiopia and the origin of the Afar hotspot. Geology 34, 329-332.

Bijwaard, H., W. Spakman, and E. R. Engdahl, (1998). Closing the gap between regional and global travel time tomography, J. Geophys. Res., v.103, p.30,055- 30,078

Bogoyavlenskaya G.E., Braitseva O.A., Melekestsev I.V., Maksimov A.P., Ivanov B.V., (1991). Bezymianny Volcano. Active Volcanoes of Kamchatka : In 2 vol. . Moscow: Nauka, 1991. V. 1. P.195-197.

Braitseva, O., I. Melektsev, V. Ponomareva, L. Sulezhitskiy, and S. Litasova, (1994). Ages of active volcanoes in the Kuril-Kamchatka region, Volcanology and seismology, 4-5, p. 5-32 (In Russian)

Camus, G. A., P.-C. Gourgaud, Mossand-Berthommier, and P.M. Vincent, (2000), Merapi (Central Java, Indonesia): An outline of the structural and magmatological 
evolution, with a special amphasis to the major pyroclastic events. J. Volcanol. Geotherm. Res., 100, 139-163.

Chang, S.-J., Van der Lee, S., (2011). Mantle plumes and associated flow beneath Arabia and East Africa, Earth Planet. Sci. Lett. doi:10.1016/j.epsl.2010.12.050

Daly, E., D. Keir, C. J. Ebinger, G. W. Stuart, I. D. Bastow, and A. Ayele, (2008). Crustal tomographic imaging of a transitional continental rift: the Ethiopian rift, Geophys. J. Int. 172, 1033-1048, doi: 10.1111/j.1365-246X.2007.03682.x.

Dercourt, J., L. Zonenshain, L.E. Ricou, G. Kazmin, X. Le Pichon, A.L. Knipper, C. Grandjacquet, I.M. Sbortshikov, J. Geyssant, C. Lepvrier, D.H. Pechersky, J. Boulin, J.C. Sibuet, L.A. Savostin, O. Sorokhtin, M. Westphal, M.L. Bazhenov, J.P. Lauer and B. Biju-Duval (1986): Geological evolution of the Tethys belt from the Atlantic to the Pamirs since the Lias,Tectonophysics, 123, 241-315.

DeMets, C., R. Gordon, D. Argus, and S. Stein, (1990). Current plate motions, Geophys. J. Int., 101, 425-478.

De Silva, S.L. and Francis, P.W., (1991). Volcanoes of the Central Andes, Springer Verlag, 199-212 (Appendix II).

Di Stefano R. and C. Chiarabba. Active source tomography at Mt. Vesuvius: Constraints for the magmatic system. J. Geophys. Res., 107:2278, doi:10.1029/2001JB000792, 2002.

Eskin A.C., A.A.Bukharov, Yu.A.Zorin, 1978. Cenozoic magmatizm of lake Baikal, Doklady AN SSSR, v. 239, n.4, p. 926-929.

Evans, J., Achauer, U., 1993. Teleseismic velocity tomography using the ACH method: theory and application to continental-scale studies. In: Iyer, H.M., Hirahara, K. (Eds.), Seismic Tomography: Theory and Practice. Chapman and Hall, London, pp. 319-360.

Faccenna, C., Jolivet, L., Piromallo, C. \& Morelli, A., (2003). Subduction and the depth of convection in the Mediterranean mantle, J. Geophys. Res., 108(B2), 2099, doi:10.1029/2001JB001690.

Fedotov S.A., Zharinov N.A., Gontovaya L.I., (2010). The magmatic system of the Klyuchevskaya Group of volcanoes inferred from data on its eruptions, earthquakes, deformation and deep structure. Volcanology and Seismology, 1, p. 335 (in Russian).

Gibson, R.L., and M.N.Toksoz, (1990). Permeability estimation from velocity anisotropy in fractured rocks, J.Geophys.Res., 95, 15643-15655.

Gorbatov A, Fukao Y, Widiyantoro S, Gordeev E, (2001). Seismic evidence for a mantle plume oceanwards of the Kamchatka-Aleutian trench junction, Geophysical Journal International, Volume 146, Issue 2, pp. 282-288.

Gorshkov G.S., Bogoyavlenskaya G.E., (1965). The Bezymianny Volcano and peculiarity of the last eruption (1955-1956). Moscow, Nauka, 165 p.

Granet, M., Wilson, M., and Achauer, U., (1995), Imaging a mantle plume beneath the French Massif Central: Earth and Planetary Science Letters, v. 136, p. 281-296.

Haberland, C., A. Riebrock, B. Schurr, and H. Brasse, (2003). Coincident anomalies of seismic attenuation and electrical resistivity beneath the southern Bolivian Altiplano plateau, Geophys. Res. Lett., 30(18), 1923, doi: 10.1029/2003GL017492. 
Hansen, S., Schwartz, S., Al-Amri, A., Rodgers, A., (2006). Combined plate motion and density-driven flow in the asthenosphere beneath Saudi Arabia: evidence from shear-wave splitting and seismic anisotropy. Geology 34, 869-872. doi:10.1130/ G22713.1. International Seismological Centre, 2001, Bulletin Disks 1-9 [CD-ROM], Internatl. Seis. Cent., Thatcham, United Kingdom.

Ivanov, V.V. (2008). Current cycle of the Kluchevskoy volcano activity in 1995-2008 based on seismological, photo, video and visual data. in Proceedings of Conference, Petropavlovsk-Kamchatsky, 27-29 march, 100-109.

Jakovlev A., G. Rümpker, M.Lindenfeld, I.Koulakov, A.Schumann, N. Ochmann, (2011), Crustal seismic velocities from local travel-time tomography: a case study from the Rwenzori Mountains of the East African Rift, BSSA; v. 101; no. 2; p. 848-858; DOI: $10.1785 / 0120100023$

Jung, H., and S.Karato, (2001). Water-induced fabric transitions in olivine. Science 293 (5534), 1460-1463.

Khrenov A.P., Antipin V.S., Chuvashova L.A., Smirnova E.V. (1989). Petrochemical and geochemical peculiarity of basalts of the Kluchevskoy volcano. Volcanology and seismology. 3, p.3-15.

Khubunaya S., L.Gontovaya, A. Sobolev, and I. Nizkous (2007). Magmatic sources beneath the Kluchevskoy volcano group (Kamchatka). Volcanology and seismology, 2, P 2242

Koulakov, I. (2011). High-frequency P and S velocity anomalies in the upper mantle beneath Asia from inversion of worldwide traveltime data, J. Geophys. Res., 116, B04301, doi:10.1029/2010JB007938

Koulakov, I., E. I. Gordeev, N. L. Dobretsov, V. A. Vernikovsky, S. Senyukov, and A. Jakovlev (2011a), Feeding volcanoes of the Kluchevskoy group from the results of local earthquake tomography, Geophys. Res. Lett., 38, L09305, doi:10.1029/2011GL046957

Koulakov I.Yu., N.L. Dobretsov, N.A. Bushenkova , A.V. Yakovlev, (2011b). Slab shape in subduction zones beneath the Kurile-Kamchatka and Aleutian arcs based on regional tomography results, Russian Geology and Geophysics 52, 650-667

Koulakov I., and N. Bushenkova, (2010), Upper mantle structure beneath the Siberian craton and surrounding areas based on regional tomographic inversion of P and PP travel times, Tectonophysics, 486, 81-100.

Koulakov I., M.K. Kaban, M. Tesauro, and S. Cloetingh, (2009a). P and S velocity anomalies in the upper mantle beneath Europe from tomographic inversion of ISC data, Geophys. J. Int. 179, 1, p. 345-366. doi: 10.1111/j.1365-246X.2009.04279.x

Koulakov I., T. Yudistira, B.-G. Luehr, and Wandono, (2009b). P, S velocity and VP/VS ratio beneath the Toba caldera complex (Northern Sumatra) from local earthquake tomography, Geophys. J. Int., 177, p. 1121-1139, doi: 10.1111/j.1365246X.2009.04114.x

Koulakov, I., A. Jakovlev, and B. G. Luehr (2009c). Anisotropic structure beneath central Java from local earthquake tomography, Geochem. Geophys. Geosyst., 10, Q02011, doi:10.1029/2008GC002109. 
Koulakov I., (2009a). LOTOS code for local earthquake tomographic inversion. Benchmarks for testing tomographic algorithms, Bulletin of the Seismological Society of America, Vol. 99, No. 1, pp. 194-214, doi: 10.1785/0120080013

Koulakov I., (2009b). Out-of-network events can be of great importance for improving results of local earthquake tomography, Bulletin of the Seismological Society of America, Vol. 99, No. 4, pp. 2556-2563, doi: 10.1785/0120080365

Koulakov I.Y., (2008). Upper mantle structure beneath southern Siberia and Mongolia, from regional seismic tomography, Russian Geology and Geophysics Volume 49, Issue 3, Pages 187-196

Koulakov, I. (2007). Structure of the Afar and Tanzania plumes based on the regional tomography using ISC data, Doklady Earth Sciences 417 No. 8 1287-1292

Koulakov I., M. Bohm, G. Asch, B.-G. Lühr, A.Manzanares, K.S. Brotopuspito, Pak Fauzi, M. A. Purbawinata, N.T. Puspito, A. Ratdomopurbo, H.Kopp, W. Rabbel, E.Shevkunova (2007), P and S velocity structure of the crust and the upper mantle beneath central Java from local tomography inversion, J. Geophys. Res., 112, B08310, doi:10.1029/2006JB004712.

Koulakov, I., S.V.Sobolev, and G. Asch, (2006). P- and S-velocity images of the lithosphereasthenosphere system in the Central Andes from local-source tomographic inversion, Geophys. Journ. Int., 167, 106-126.

Lavecchia G. \& Stoppa F. (1996) - The tectonic significance of Italian magmatism: an alternative view. Terra Nova, 8, 435-343

Lavecchia G., Stoppa F. \& Creati N. (2006) Carbonatites and kamafugites in Italy: mantlederived rocks that challenge subduction. Annals of Geophysics, supplement to vol 49, 389-402.

Laverov N.P., (2005). Modern and Holocene volcanism in Russia, Moscow, Nauka, 604 p.

Lees J.M. and H. Wu, (1999). P wave anisotropy, stress, and crack distribution at Coso geothermal field, California, Journal of Goephys. Res., V. 104, N B8, p. 1795517973.

Logachev, N.A., (2005). History and geodynamics of the Baikal rift, in: Goldin, S.V., Mazukabzov, A.M., Seleznev, B.C. (Eds.), Actual Problems of Modern Geodynamics of Asia [in Russian]. Izd. SO RAN, Novosibirsk, pp. 9-32.

Logachev, N.A., S.V.Rasskazov, A.V.Ivanov, K.G.Levi, A.A.Bukharov, S.A.Kashik, and S.I.Sherman, (1996). Cenozoic rifting in continental lithosphere, in: Logachev, N.A. (Ed.), Lithosphere of Central Asia [in Russian], Nauka, Novosibirsk, pp. 57-80.

Lustrino, M. (2000): Volcanic activity during the Neogene to Present evolution of the Western Mediterranean area: a review, Ofioliti, 25, 87-101.

Montelli, R., Nolet, G., Dahlen, F.A., Masters, G., Engdahl, E.R., and Hung, S.-H., 2004, Finite-Frequency Tomography Reveals a Variety of Plumes in the Mantle: Science, v. 303, p. 338-343.

Newhall, C.G., Bronto, S., Alloway, B., Banks, N.G., Bahar, I. \& Marmol, M.A.D., (2000). 10000 Years of explosive eruptions of Merapi volcano, Central Java: Archaeological and Modern Implications, Journal of Volcanological and Geothermal Research, 100, $9-50$ 
Nikulin, A., V. Levin, A. Shuler, and M. West (2010), Anomalous seismic structure beneath the Klyuchevskoy Group, Kamchatka, Geophys. Res. Lett., 37, L14311.

Nizkous, I., Sanina, I., Kissling, E., Gontovaya, L. (2006): Velocity properties of oceancontinent transition zone lithosphere in Kamtchatka region according to seismic tomography data. Physics of the solid Earth 42 (4): 286-296

Ozerov A.Y., Ariskin A.A., Kyle P., Bogoyavlenskaya G.E., Karpenko S.F. (1997). A petrological-geochemical model for genetic relationships between basaltic and andesitic magmatism of Klyuchevskoi and Bezymyannyi volcanoes, Kamchatka, Petrology, 5, p. 550-569.

Ozerov A.Yu., Firstov P.P., Gavrilov V.A. (2007) Periodicities in the Dynamics of Eruptions of Klyuchevskoi Volcano, Kamchatka. in Volcanism and Subduction: The Kamchatka Region. Geophysical Monograph Series, v.172, 2007, P. 283-291.

Park, Y. and A. A. Nyblade (2006), P-wave tomography reveals a westward dipping low velocity zone beneath the Kenya Rift, Geophys. Res. Lett., vol. 33, L07311, doi:10.1029/2005GL025605.

Park, Y., Nyblade, A.A., Rodgers, A.J., Al-Amri, A., (2007). Uppermantle structure beneath the Arabian Peninsula and northern Red Sea from teleseismic body wave tomography: implication for the origin of Cenozoic uplift and volcanism in the Arabian Shield. Geochem. Geophys. Geosyst. 8, Q06021. doi:10.1029/2006GC001566.

Park, Y., Nyblade, A.A., Rodgers, A.J., Al-Amri, A., (2008). S wave velocity structure of the Arabian Shield upper mantle from Rayleigh wave tomography. Geochem. Geophys. Geosyst. 9, Q07020. doi:10.1029/2007GC001895.

Patanè D, Barberi G, Cocina O, De Gori P, Chiarabba C, (2006). Time-resolved seismic tomography detects magma intrusions at Mount Etna. Science, 313(5788):821-3

Paulatto M., T.A. Minshull, B. Baptie, S. Dean, J.O.S. Hammond, T. Henstock, C.L. Kenedi, E.J. Kiddle, P. Malin, C. Peirce, G. Ryan, E. Shalev, R.S.J. Sparks, and B. Voight. (2010). Upper crustal structure of an active volcano from refraction/reflection tomography, Montserrat, Lesser Antilles. Geophys. J. Int., xxx:X-XX.

Piromallo, C., and Morelli, A., (2003). P wave tomography of the mantle under the Alpine Mediterranean area: Journal of Geophysical Research, v. 108, B2, 2065, doi:10.1029/2002JB001757.

Poli, S., \& M.W. Schmidt, (1995). H2O transport and release in subduction zones: Experimental constrains on basaltic and andesitic systems, J.Geophys. Res., 100, 22299-22314.

Rasskazov S.V., (1993). Magmatism of the Baikal rift zone, Novosibirsk, Nauka, 288 p. (in Russian).

Ritter, J.R.R., Jordan, M., Christensen, U., Achauer, U., (2001). A mantle plume beneath the Eifel volcanic field, Germany, Earth Planet. Sci. Lett., 186, 7-14.

Scheuber, E., T. Bogdanic, A. Jensen, and K.-J Reutter, (1994). Tectonic development of the north Chilean Andes in relation to plate convergence and magmatism since the Jurassic, in Tectonics of the Southern Central Andes, edited by K.-J. Reutter, E. Scheuber, and P. Wigger, pp. 121-139, Springer-Verlag, New York, 1994. 
Schurr, B., G.Asch, A.Rietbrock, R.Kind, M.Pardo, B.Heit, and T.Monfret, (1999). Seismicity and average velocity beneath the Argentine Puna, Geophys. Res. Lett., 26, 30253028.

Schurr, B., (2001). Seismic structure of the Central Andean Subduction Zone from Local Earthquake Data, STR01/01, PhD thesis, GFZ-Potsdam.

Schurr, B., G. Asch, A. Rietbrock, R. Trumbull, and C. Haberland, (2003). Complex patterns of fluid and melt transport in the central Andean subduction zone revealed by attenuation tomography, Earth and Planetary Science Letters 215 105-119.

Smith, R. L. \& Bailey, R. A., (1968). Resurgent cauldrons. In: Coats, R. R., Hay, R. L. \& Anderson, C. A. (eds) Studies in Volcanology. Geological Society of America, Memoir 116, 613-662.

Sobolev, S.V., Zeyen, H., Granet, M., Achauer, U., Bauer, C., Werling, F., Altherr, R., and Fuchs, K., (1997). Upper mantle temperatures and lithosphere-asthenosphere system beneath the French Massif central constrained by seismic, gravity, petrologic and thermal observations: Tectonophysics, v. 275, p. 143-164.

Stankiewicz, J., T. Ryberg, C. Haberland, Fauzi, and D. Natawidjaja, (2010). Lake Toba volcano magma chamber imaged by ambient seismic noise tomography, Geophys. Res. Lett., 37, L17306, doi:10.1029/2010GL044211.

Tongue, J. A., (1992). Tomographic study of local earthquake data from the Lake Bogoria region of the Kenya Rift Valley, Geophys. Journ. Int., 109, 249 - 258.

VanDecar, J. C., and R. S. Crosson, (1990). Determination of teleseismic relative phase arrival times using multi-channel cross-correlation and least-squares, Bull. Seismol. Soc. Am., 80, 150-169.

Wagner D., I. Koulakov, W. Rabbel, B.-G. Luehr, A. Wittwer, H. Kopp, M. Bohm, G. Asch, MERAMEX Scientists, (2007) Joint inversion of active and passive seismic data in Central Java // Geophysical Journal International.V 170, p. 923-932, doi:10.1111/ j.1365-246X.2007.03435.x

Yarmoluk, V.V., V.I.Kovalenko, and O.A.Bogatikov, 1990. South-Baikal "Hot spot" in the mantle and its role in development of the Baikal rift zone, Doklady AN SSSR, v. 312, n. 1, p. 187-191.

Zandomeneghi D., A. H. Barclay, J. Almendros, J. M. Ibáñez, W. S. D. Wilcock, and T. BenZvi. (2009). Crustal structure of Deception island volcano from p-wave seismic tomography: Tectonic and volcanic implications. J. Geophys. Res., 114:B06310.

Zollo A., L. D'Auria, R.De Matters, A. Herrero, J. Virieux, and P. Gasparini. (2002). Bayesia estimation of $2 \mathrm{~d}$ p-velocity models from active seismic arrival time data: Imaging of the shallow structure of mt. vesuvius (southern italy). Geophys. J. Int., 151:566-582.

Zollo A., S. Judenherc, E. Auger, L. D'Auria, J. Virieux, P. Capuano, C. Chiarabba, R. de Franco, J. Makris, A. Michelini, and G. Musacchio. (2003). Evidence for the buried rim of Campi Flegrei caldera from 3D active seismic imaging. Geophys. Res. Letters, 30:10.1029,

Zorin, Yu.A., V.V. Mordvinova, E.Kh. Turutanov, B.G. Belichenko, A.A. Artemyev, G.L. Kosarev, and S.S. Gao, (2002). Low seismic velocity layers in the Earth's crust beneath Eastern Siberia (Russia) and Central Mongolia: receiver function data their possible geological implication, Tectonophysics, v. 359, p. $307-327$. 
Zorin Y. A., E. Kh. Turutanov, V. V. Mordvinova, V. M. Kozhevnikov, T. B. Yanovskaya, and A. V. Treussov, (2003). The Baikal rift zone: the effect of mantle plumes on older structure, Tectonophysics, v. 271, p. 153 - 173.55-75. 


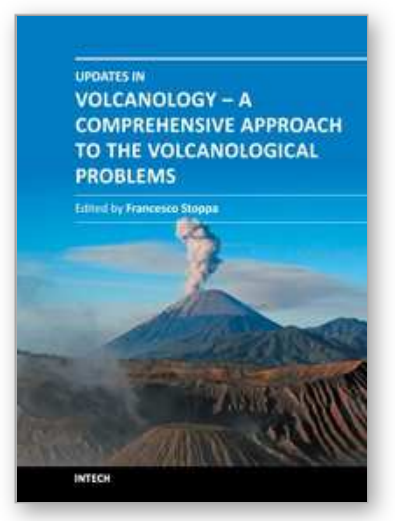

\section{Updates in Volcanology - A Comprehensive Approach to Volcanological Problems}

Edited by Prof. Francesco Stoppa

ISBN 978-953-307-434-4

Hard cover, 242 pages

Publisher InTech

Published online 13, January, 2012

Published in print edition January, 2012

This book ranges from the geologic-petrologic description of world-wide major volcanic fields unfamiliar to international literature, to the discussion and interpretation of the results in light of geophysical techniques. It focuses on several situations that represent large-scale volcanism on Earth, related both with intra-plate or active margins. Many large volcanic complexes of Easter countries are presented, including Japan, Siberian Russia, and Mongolia. A detailed account of the European volcanic province of the Pannonia basin and Central-Southern Spain is given. Southern hemisphere areas of Antarctica and Polynesia are considered as well. The chapters are very informative for those who wish for a guide to visiting, or are curious about main characteristics of the above volcanic areas, some of which are remote and not easily accessible.

\section{How to reference}

In order to correctly reference this scholarly work, feel free to copy and paste the following:

Ivan Koulakov (2012). Multiscale Seismic Tomography Imaging of Volcanic Complexes, Updates in Volcanology - A Comprehensive Approach to Volcanological Problems, Prof. Francesco Stoppa (Ed.), ISBN: 978-953-307-434-4, InTech, Available from: http://www.intechopen.com/books/updates-in-volcanology-acomprehensive-approach-to-volcanological-problems/multiscale-seismic-tomography-imaging-of-volcaniccomplexes

\section{INTECH}

open science | open minds

\author{
InTech Europe \\ University Campus STeP Ri \\ Slavka Krautzeka 83/A \\ 51000 Rijeka, Croatia \\ Phone: +385 (51) 770447 \\ Fax: +385 (51) 686166 \\ www.intechopen.com
}

\author{
InTech China \\ Unit 405, Office Block, Hotel Equatorial Shanghai \\ No.65, Yan An Road (West), Shanghai, 200040, China \\ 中国上海市延安西路65号上海国际贵都大饭店办公楼405单元 \\ Phone: +86-21-62489820 \\ Fax: +86-21-62489821
}


(C) 2012 The Author(s). Licensee IntechOpen. This is an open access article distributed under the terms of the Creative Commons Attribution 3.0 License, which permits unrestricted use, distribution, and reproduction in any medium, provided the original work is properly cited. 